Monika Nawrot-Borowska

Zaktad Teorii Wychowania i Deontologii Nauczycielskiej

Instytut Pedagogiki

Uniwersytet Kazimierza Wielkiego w Bydgoszczy

\title{
Zabawy i zabawki dziecięce w drugiej połowie XIX i na początku XX wieku - wybrane problemy $z$ wykorzystaniem grafik $z$ epoki
}

\begin{abstract}
Games and children's toys in the second half of the nineteenth and early twentieth centuries - selected aspects of using graphics from the period

The aim of the article is to present aspects of selected games and children's toys in the second half of the nineteenth and early twentieth centuries. The inspiration for the consideration will be graphics from the press and (mainly children's) literature of the period, accompanied by a description of the games and toys presented in them. The sources providing the graphics will be educational literature and guides, and guides to the health and hygiene of children and teenagers. These texts can be useful in studying history, whether in the classroom or during seminars on the history of education.
\end{abstract}

Keywords: fun, toy, childhood, 19th century, iconography

\section{Wprowadzenie - o znaczeniu ikonografii w badaniach historyczno-pedagogicznych i nauczaniu historii zabaw i zabawek dziecięcych}

Zabawa - dominująca aktywność charakterystyczna dla wieku dziecinnego, niezwykle istotny element życia człowieka dorosłego oraz zabawka - nieodłączny element i atrybut czynności zabawowych towarzyszą człowiekowi od najdawniejszych czasów. Zabawy i zabawki ludzi w minionych wiekach stały się przedmiotem badań naukowców $\mathrm{z}$ wielu dziedzin. Pozwalają one nie tylko lepiej poznać przeszłość materialną i poziom cywilizacyjny danej epoki, ale także zrozumieć pewne formy zachowań człowieka, istotne aspekty jego życia i funkcjonowania. Specyfika zabaw i zabawek minionej przeszłości stała się niezwykle interesującym i wartościowym poznawczo obszarem eksploracji naukowych także z tego względu, iż pozwala dostrzec swoistą ciągłość i zmianę specyfiki zachowań ludycznych minionej przeszłości i współczesności, ukazać pewne ich formy, 
które, mimo upływającego czasu i zmieniających się warunków cywilizacyjnych, pozostają niezmiennie takie same. W ostatnich latach problematyka ludyzmu stała się także obszarem dociekań historyków wychowania, którzy coraz więcej uwagi poświęcają zabawom i zabawkom dziecięcym ${ }^{1}$.

Pomysł prezentacji problematyki zabaw i zabawek dziecięcych z wykorzystaniem grafik z epoki narodził się na skutek doświadczeń autorki tekstu, która tego typu materiały wykorzystuje podczas zajęć dydaktycznych z historii edukacji, a także podczas zajęć fakultatywnych poświęconych zabawom i zabawkom minionych wieków. Podkreślić bowiem należy, że materiały ikonograficzne są cennym, lecz stosunkowo rzadko wykorzystywanym źródłem do dziejów historii edukacji. Analiza wskazanego typu źródeł bywa często pomijana podczas zajęć dydaktycznych z historii wychowania, czy historii myśli pedagogicznej, których realizacja zdominowana została przez studiowane źródeł pisanych. Dzieje się tak z pewnością nie bez przyczyny - publikowane teksty źródłowe rzadko zawierają materiał ikonograficzny, zaś jego gromadzenie na potrzeby zajęć zajmuje sporo czasu i wymaga wielu poszukiwań. Warto jednak takie materiały gromadzić, mogą one bowiem w cenny sposób wzbogacić wiedzę z danego okresu historycznego, stanowiąc ważny i bardzo interesujący dla odbiorcy sposób przedstawienia wydarzeń historycznych i faktów związanych z problematyką edukacyjną. Materiały ikonograficzne są bowiem nie tylko dziełami sztuki, ale stanowią wartościowy nośnik informacji, cennych z punktu widzenia badań historycznych. W ostatnim czasie znacznie wzrosła ich dostępność, dzięki bogatym i stale powiększanym zasobom bibliotek cyfrowych, w których znaleźć można bardzo wiele zdigitalizowanych materiałów źródłowych z XIX i początku XX w., także ikonograficznych, co powinno zachęcić zainteresowanych do poszukiwań i analiz.

Podkreślić należy, że metoda ikonograficzna polega nie tyle na prezentacji materiału ikonograficznego, ile na jego analizie jako źródła historycznego - więc na próbie odczytania treści jego przekazu. Mimo że język obrazu jest językiem pozornie zrozumiałym dla każdego, często jest to jedynie pozorne, zaś odkrywania głębszych warstw przekazu zawartego w tego typu źródłach trzeba się nauczyć. Nie jest to zadaniem łatwym i nadal pozostaje domeną historyków sztuki i źródłoznawców². W pracy nad źródłem historycz-

1 Patrz np.: K. Kabacińska, Zabawy i zabawki w osiemnastowiecznej Polsce, Poznań 2007; eadem, W co i jak bawily się polskie dzieci $w$ XVIII wieku?, w: Dziecko w rodzinie i społeczeństwie. Dzieje nowożytne, red. K. Jakubiak, W. Jamrożek, Bydgoszcz 2002, t. II, s. 87-100; eadem, Zabawy i zabawki dziecięce w czasopiśmiennictwie dziewiętnastowiecznym na przyktadzie „Kroniki Rodzinnej”, w: Czasopiśmiennictwo XIX i początków XX wieku jako źródło do historii edukacji, red. I. Michalska, G. Michalski, Łódź 2010, s. 147-158; R. Kantor, R. Zięzio, Zabawy i zabawki w życiu polskich dzieci w XIX i XX wieku, w: Od narodzin do wieku dojrzałego. Dzieci i młodzież w Polsce, część II - stulecie XIX i XX, red. E. Mazur, Warszawa 2003, s. 247-260; B. Pilichowska, Zabawy i zabawki chłopięce w XIX-wiecznym Krakowie, ,Zabawy i Zabawki” 1997, nr 1-2, s. 63-76; Zabawy $i$ zabawki, w: A. Bołdyrew, Matka i dziecko rodzinie polskiej. Ewolucja modelu życia rodzinnego w latach 1795-1918, Warszawa 2008, s. 152-156; Zabawy i zabawki, w: A. Pachocka, Dzieciństwo we dworze szlacheckim w I połowie XIX wieku, Kraków 2009, s. 189-209; Dawne zabawy dziecięce, red. D. Żołądź-Strzelczyk, K. Kabacińska, Kielce-Warszawa 2008; Dawne i współczesne zabawki dziecięce, red. D. Żołądź-Strzelczyk, K. Kabacińska, Poznań 2010.

2 Patrz np.: P. Stróżyk, Źródła ikonograficzne w badaniu źródłoznawczym, na przykładzie drzwi gnieźnieńskich, Poznań 2011; M. Fabiański, Dzieło sztuki. Źródło ikonograficzne czy coś więcej?, Warszawa 2005; Tekst 
nym należy także pamiętać, jak pisał o tym J. Topolski, iż nie jest ono jako takie źródłem prawdy [...] źródło jest także wytworem ludzi mających określone poglądy3. Źródeł ikonograficznych nie można więc uznać za w pełni obiektywne źródło historyczne. Pamiętać trzeba o możliwości subiektywnej interpretacji wydarzeń autora dzieła i jego inwencji twórczej, która nie zawsze mogła pozostawać w zgodzie z prawdą historyczną. Jednak pomimo pojawiających się podczas analizy prezentowanego rodzaju źródeł trudności natury metodologicznej, warto wykorzystywać materiały ikonograficzne choćby jako materiał ilustracyjny, tematycznie związany z przedmiotem prowadzonych zajęć, stanowiący cenne uzupełnienie tekstów pisanych dotyczących analizowanej problematyki przedmiotu. Dla historyka wychowania zainteresowanie źródłami ikonograficznymi może mieć istotne znaczenie w stałej ich konfrontacji ze źródłami pisanymi ${ }^{4}$.

Źródła ikonograficzne - a więc m.in.: obrazy, malowidła, rzeźby, ryciny, drzeworyty, rysunki, karykatury, szkice, fotografie, pozwalają na chwilę zatrzymać czas - przekazując nam obraz tego, co działo się w jakimś momencie historii, ukazując, jak wyglądała codzienność i życie ludzi danej epoki, chwile smutku i radości, pracy i zabawy. Pozwalają one przyjrzeć się, jak w minionych wiekach wyglądały stroje, wnętrza mieszkalne, przedmioty użytkowe - także zabawki. Ukazują kadry z życia dzieci i ich edukacji w rodzinach możnych i ubogich - w przypadku wieku XIX i początku XX w. - od arystokratycznych po chłopskie. Dzięki przebogatej wizualizacji życia rodzinnego, prezentowanego przez XIX-wiecznych malarzy, grafików czy fotografów, możemy śledzić nie tylko jak wyglądało, ale i jak zmieniało się życie i rzeczywistość edukacyjna rodzin polskich na przestrzeni wieku XIX i w początku wieku XX, w tym także, jakie były oraz jak zmieniały się zabawy i zabawki dziecięce.

Intencją autorki niniejszego tekstu jest przesłanie historykom wychowania i nauczycielom historii sugestii, aby nie marginalizowali źródeł wizualnych, które mogą w bardzo istotny sposób wzbogacić ich zajęcia dydaktyczne i urozmaicić analizę źródeł opartą niemal wyłącznie na tekstach pisanych. Ma on także na celu ukazanie i podkreślenie znaczenia interdyscyplinarnego warsztatu historyka edukacji, w którym obok tradycyjnie wykorzystywanych źródeł pisanych ważną rolę odgrywają źródła ikonograficzne.

Prezentowany poniżej tekst podzielony został na dwie części. W pierwszej z nich omówione zostały czynniki warunkujące zabawy dzieci z różnych warstw społecznych. W części drugiej zaprezentowano wybrane problemy dotyczące zabaw i zabawek dziecięcych. Wszystkie części zilustrowane zostały materiałami ikonograficznymi - grafikami.

źródła - krytyka, interpretacja, red. B. Trelińska, Warszawa 2005; M. Giermakowski, Źródła ikonograficzne w edukacji historycznej, „Wiadomości Historyczne” 2007, nr 5, s. 38-43; H. Figaj-Nowak, Dydaktyczna interpretacja źródła ikonograficznego, w: Uczeń w Nowej Szkole. Edukacja humanistyczna, red. M. Kujawska, Poznań 2002, s. 189-194; W. Ławniczak, Teoretyczne podstawy interpretacji dziel sztuki plastycznej, Poznań 1975.

3 J. Topolski, Wprowadzenie do historii, Poznań 1998, s. 55.

${ }^{4}$ Zob.: M. Nawrot-Borowska, Wybór materiałów ikonograficznych z zakresu edukacji domowej dzieci polskich $w$ latach 1850-1914, w: Wychowanie - opieka - kształcenie: z badań nad wybranymi problemami edukacji w XX i XXI wieku, red. M. Brodnicki, E. Gorloff, A. Kołakowski, Toruń 2010, s. 183-197. 
Przedstawione poniżej fakty i uogólnienia pochodzą z prowadzonych do tej pory przez autorkę badań poświęconych zabawom i zabawkom dzieci polskich z różnych warstw społecznych w okresie drugiej połowy XIX i początku XX w. zarówno w aspekcie zapatrywań teoretycznych, jak i praktyki ${ }^{5}$. Fragmenty cytatów źródłowych wykorzystane w drugiej części tekstu zaczerpnięto z poradników wychowawczych, higienicznych, artykułów prasowych oraz pamiętników i wspomnień badanego okresu. Wykorzystane jako materiał ilustracyjny grafiki pochodzą z czasopism ilustrowanych, głównie kobiecych i rodzinnych, a także literatury dla dzieci i młodzieży z drugiej połowy XIX i początku XX w.

\section{Jak, kiedy, czym i z kim się bawiono - czynniki warunkujące zabawy dziecięce}

Analizując tytułową problematykę, należy mieć na uwadze kilka czynników warunkujących rodzaje i specyfikę zabaw i zabawek dziecięcych. Czynniki te podzielić można zewnętrzne i wewnętrzne. Zewnętrzne to warstwa społeczna, do której należało dziecko, majętność rodziny, miejsce zamieszkania, pora roku, warunki atmosferyczne, tryb życia rodziny i dziecka, towarzystwo. Do czynników wewnętrznych zaliczyć można wiek i płeć dziecka, poziom jego rozwoju, stan zdrowia, temperament oraz wyobraźnię.

Przede wszystkim o bogactwie zabaw, w jakie bawili się najmłodsi, decydowała ich przynależność do warstwy społecznej, status społeczno-materialny rodziny. Ten czynnik uznać można za najistotniejszy, warunkujący niemal wszystkie pozostałe. Choć rodzaje zabaw często były zbliżone u dzieci ze wszystkich stanów, to specyfika ich przebiegu, organizacji była odmienna. Inaczej więc bawiły się dzieci chłopskie, inaczej mieszczańskie (inteligenckie czy robotnicze), inaczej ziemiańskie czy arystokratyczne.

Na specyfikę zabaw dziecinnych wpływało też w znacznym stopniu miejsce zamieszkania, tworzące przestrzeń zabawy. Miejscem zabaw dziecięcych, szczególnie w dni jesienno-zimowe lub, kiedy pogoda nie dopisywała, była oczywiście przestrzeń domu. Na wsi chłopskie chaty, składające się często z jednej izby, nie pozostawiały zbyt wiele miejsca dla dziecięcych uciech. Najczęściej dzieci spędzały czas na zapiecku, starając się nie przeszkadzać domownikom w ich codziennych pracach. W bogatych domach chłopskich, gdzie izb było więcej, dzieci często nie miały do nich wstępu. Równie niewiele

\footnotetext{
${ }_{5}^{5}$ Zob np.: M. Nawrot-Borowska, Zabawki dzieci polskich $w$ drugiej połowie XIX i na początku XX wieku - zapatrywania teoretyczne, w: Dawne i wspótczesne zabawki dziecięce, dz. cyt., s. 173-190; eadem, Dole $i$ niedole dziecka wiejskiego na terenie ziem polskich $w$ II połowie XIX $i$ w poczatku XX wieku w świetle literatury pamiętnikarskiej, „Problemy Wczesnej Edukacji” nr 1 (11) 2010, s. 182-197; eadem, Kolorowy świat zabaw i zabawek dziecięcych, w: Co oferuje współczesny żłobek? Medyczne, psychologiczne i pedagogiczne aspekty wspomagania rozwoju dzieci do lat 3, red. M. Wójtowicz-Dacka, I. Laskowska, Bydgoszcz 2010, s. 189-21; eadem, Zabawy dzieci polskich $w$ drugiej połowie XIX i na początku XX wieku w świetle zapatrywań teoretycznych, w: Prace Katedry Historii Edukacji i Wychowania w Rodzinie, t. 2: Kultura, edukacja, rodzina, gender studies. Antyk-Polska, red. B. Stawoska-Jundziłk, Bydgoszcz 2011, s. 195-220; eadem, Zabawy dzieci na wsi polskiej w II połowie XIX i na początku XX wieku w świetle literatury pamiętnikarskiej, „Przegląd Pedagogiczny" 2011, nr 2 s. 39-64; eadem, Zabawy dzieci ziemiańskich w II połowie XIX i na poczatku wieku XX w świetle pamiętnikarstwa, ,Biuletyn Historii Wychowania” 29 (2013), s. 43-71.
} 
miejsca do zabaw miały dzieci robotnicze, zamieszkujące często w niewielkich izbach w sutenerach kamienic. Inaczej było w przypadku dzieci ziemiańskich, arystokratycznych czy nawet mieszczańskich, gdzie dwory, pałace czy mieszkania w kamienicach, pełne licznych pomieszczeń, tajemniczych zakamarków od strychu po piwnice, różnorakich sprzętów, mebli stanowiły niezwykle bogate pole dla pomysłowości najmłodszych przy organizacji zabaw. Często też miejscem zabaw dzieci możnych był specjalny pokój przeznaczony do swawoli - bawialnia lub obszerny salon.

Przestrzeń zabaw znacznie rozszerzała się poza domem, na świeżym powietrzu. Dla dzieci chłopskich był to zwykle teren wiejskiej zagrody, okolicznych pól, łąk czy lasów. Podobnie było z dziećmi z rodzin ziemiańskich czy arystokratycznych, dla których teren dworu, pałacu i jego okolicy był niezwykle atrakcyjnym polem dla organizacji zabaw (z wyjątkiem tych dzieci, których nadopiekuńczy rodzice, bony czy guwernantki zabraniały niczym nieograniczonych swawoli). Jeszcze inaczej wyglądała przestrzeń zabaw dobrze sytuowanych dzieci w mieście, które wolny czas mogły spędzać w ogrodach zakładanych przy miejskich willach lub kamienicach, lub w ogrodach i parkach miejskich. Maluchy z rodzin robotniczych bawiły się na podwórkach kamienic, na ulicach, w rynsztokach, na cmentarzach.
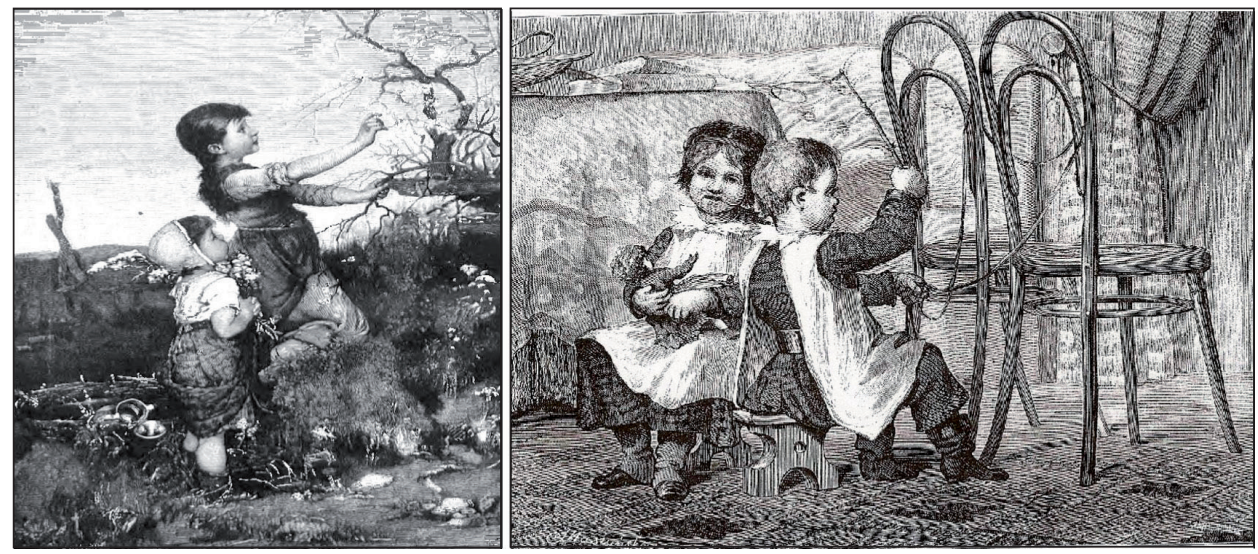

Kwiecie wiosenne, podług obrazu Kajzera, „Tygodnik Ilustrowany” 1888, nr 74 (po lewej) Jazda!..., kopia obrazu J. Maszyńskiego, „Tygodnik Ilustrowany” 1875, nr 386 (po prawej)

Pora roku i towarzysząca jej pogoda także była istotnym czynnikiem, który miał wpływ na sposób spędzania wolnego czasu i organizację gier i zabaw. Okres od wiosny do jesieni sprzyjał zabawom na powietrzu, w ogrodach, parkach, sadach, na polach, łąkach, w lasach i nad zbiornikami wodnymi. Zimą najmłodsi czas spędzali głównie w zaciszu domowym, w pałacach, dworach czy chatach, od czasu do czasu korzystając z zabaw na powietrzu. A pomysłów nie brakowało - można było ślizgać się na zamarzniętych stawach i jeziorach czy urządzanych w ogrodach ślizgawkach, saneczkować, brać udział w kuligach, bawić się w śnieżki, lepić bałwany, budować śniegowe fortece. Troskliwe 

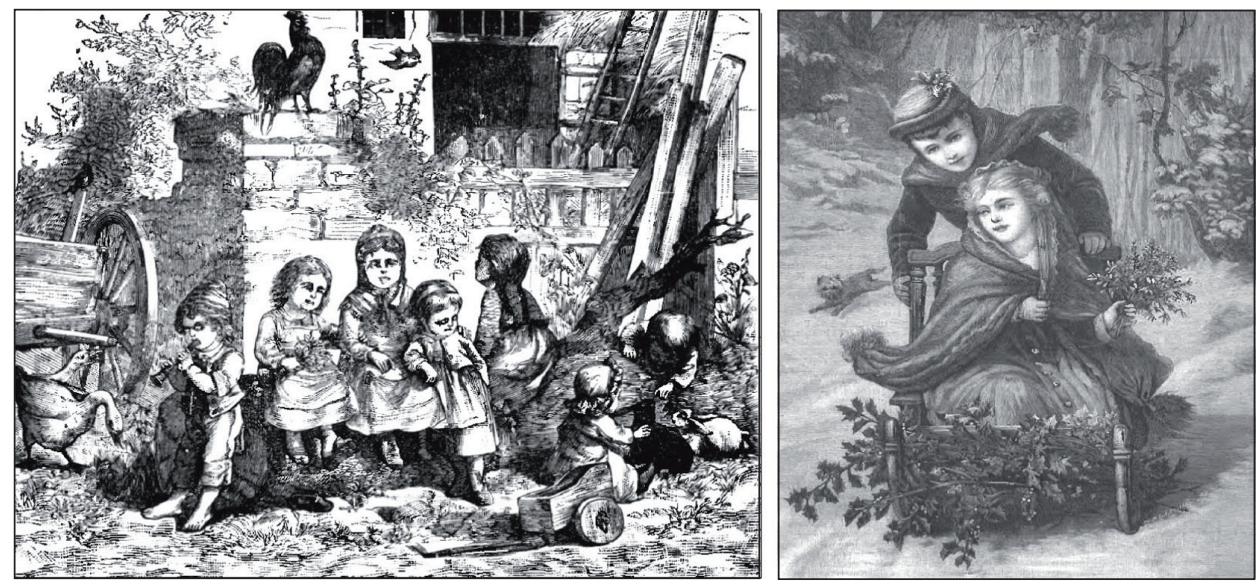

Wśród uroczego lata, „Światto” 1888, nr 8 (po lewej)

Rozrywki zimowe. Podług obrazu K. Brocharta, „Tygodnik Ilustrowany” 1881, nr 274 (po prawej)

mamy czy opiekunki możnych dzieci jednak niechętnie wypuszczały pociechy na zimno, obawiając się przeziębień czy odmrożeń. Dzieci z rodzin najuboższych, szczególnie młodsze, często nie miały ciepłej odzieży czy butów, by w takich zabawach uczestniczyć.

Z porą roku związane były także święta, obyczaje i obrzędy, które im towarzyszyły. $\mathrm{Na}$ terenie ziem polskich obchodzono wiele świąt - głównie kościelnych, wyznaczanych układem roku liturgicznego, którym towarzyszyły często różnorodne zabawy, adresowane także do najmłodszych. Najbardziej owocnym w okazje do zabaw czasem były oczywiście Święta Bożego Narodzenia i Wielkanocy, gdzie obok licznych spotkań i okazji do swobodnych harców atrakcją były prezenty - najczęściej w postaci zabawek. W czasie Gwiazdki dzieci kolędowały, tańczyły wokół choinki, dzieci chłopskie chodziły po kolędzie z gwiazdą lub turoniem. Na Wielkanoc wędrowały po wsi z gaikiem czy kogutkiem. Popularne były zabawy w zbijanie pisanek, wyścigi malowanych jaj itp. Ale i okres karnawału, na wsi zwanego zapustami był czasem tańców, zabaw, a dla dzieci możnych także balików i kuligów. Każde święto w roku miało swoje własne obrzędy, które stawały się często świetną okazją do zabawy dla najmłodszych.

Ogromne znaczenie dla przebiegu i organizacji zabaw miał styl życia, jaki wiodły dzieci. Dzieci z rodzin możnych na zabawę miały często o wiele więcej czasu niż dzieci z rodzin ubogich - robotniczych czy chłopskich. Młodsze zabawie poświęcać mogły większość swojego czasu, starsze, które podjęły już trudy nauki bawiły się w czasie wolnym od zajęć. Dzieci chłopskie często od najmłodszych lat angażowane były w prace gospodarskie, bawić się mogły więc jedynie w nielicznych wolnych chwilach, a często zabawa było organizowana przy okazji pracy, np. pasionki.

Niezwykle istotnym czynnikiem w organizacji zabaw było towarzystwo. Rodziny polskie w charakteryzowanym okresie często były wielodzietne, więc rodzeństwo zwykle 
spędzało czas wspólnie, także podczas zabawy. Warunkiem udanej zabawy był oczywiście brak zbyt dużej różnicy wieku, która utrudniała czy uniemożliwiała porozumienie. Dzieci z możnych warstw społecznych spotykały się także z innymi rówieśnikami podczas spacerów, wizyt, wyjazdów czy balików. W zaprzyjaźnionych rodzinach, gdzie było jedno lub dwoje dzieci, organizowano celowe spotkania najmłodszych w celach zabawowych. Dzieci ubogie czas spędzały wspólnie podczas pasionki, prac gospodarskich w polu, czy nielicznych chwil wolnych od pracy. Odmienną kwestią było wspólne spędzanie czasu dzieci z różnych warstw społecznych. Zwykle rodzice możni niechętnie patrzyli na kontakty swoich pociech z dziećmi służby czy okolicznych chłopów, obawiając się złego wpływu ,prostaczków” na panienki i paniczów ze dworu czy pałacu. Same dzieci, ciekawe swoich tak odmiennych światów chętnie nawiązywały kontakty, które niejednokrotnie nawet przeradzały się w przyjaźnie.

Innym czynnikiem, warunkującym czas, rodzaje, organizację i przebieg zabaw był oczywiście wiek dzieci. W warstwach zamożnych swobodne i beztroskie zabawy, trwające niemal całe dnie kończyły się około 7 roku życia, kiedy to znaczną cześć czasu dzieci zajmowała nauka domowa, na zabawę zaś pozostawał czas po lekcjach. Około 10-11 roku życia oddawano dzieci do szkół średnich - gimnazjów lub na pensje żeńskie i swobodne zabawy odbywać się mogły najczęściej podczas świąt i wakacji. Dzieci wiejskie dużo wcześniej kończyły czas swobody i zabawy, bo prace w gospodarstwie zaczynały zwykle już około 4-5 roku życia, zajmując się najczęściej pasionką, opieką nad młodszym rodzeństwem czy drobnymi pracami pomocowymi w obejściu. Również dzie-
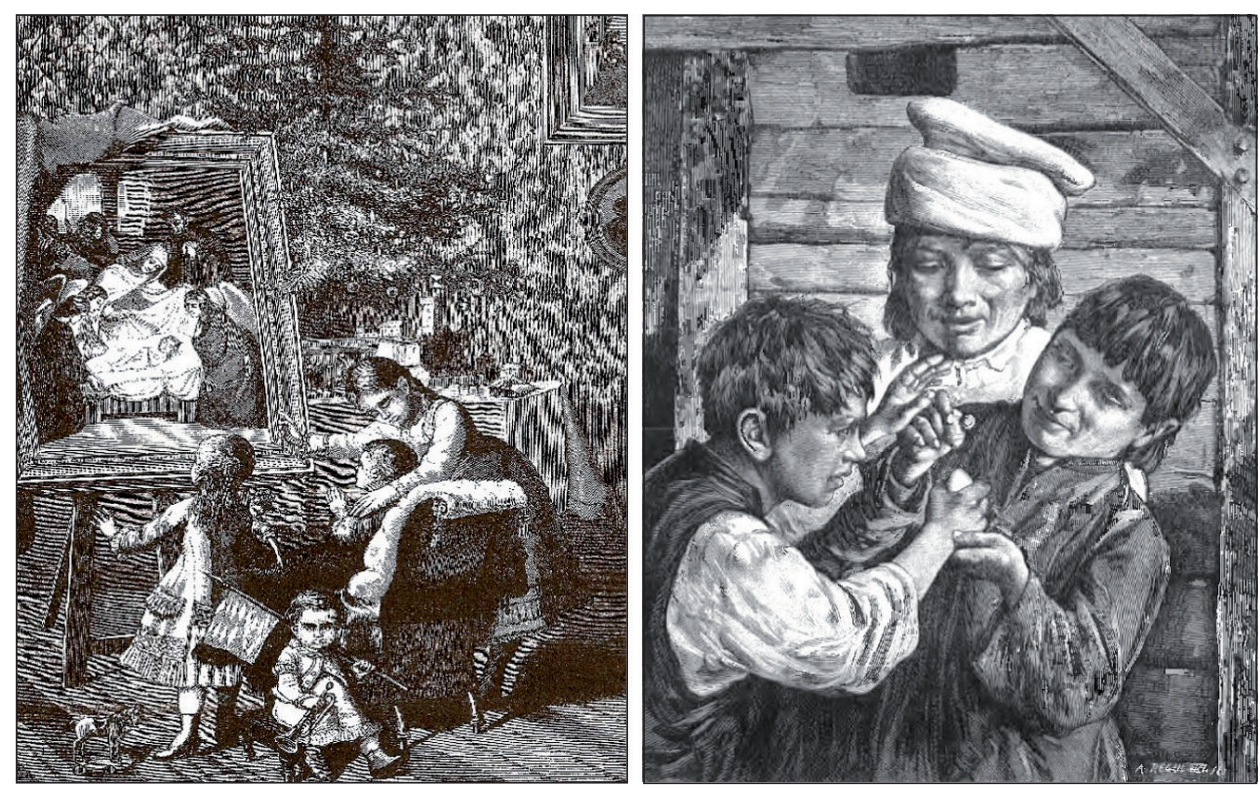

Gwiazdka, „Biesiada Literacka” 1886, nr 52 (po lewej)

Zabawa w pisanki, rys. Fałat, „Tygodnik Ilustrowany” 1884, nr 69 (po prawej) 

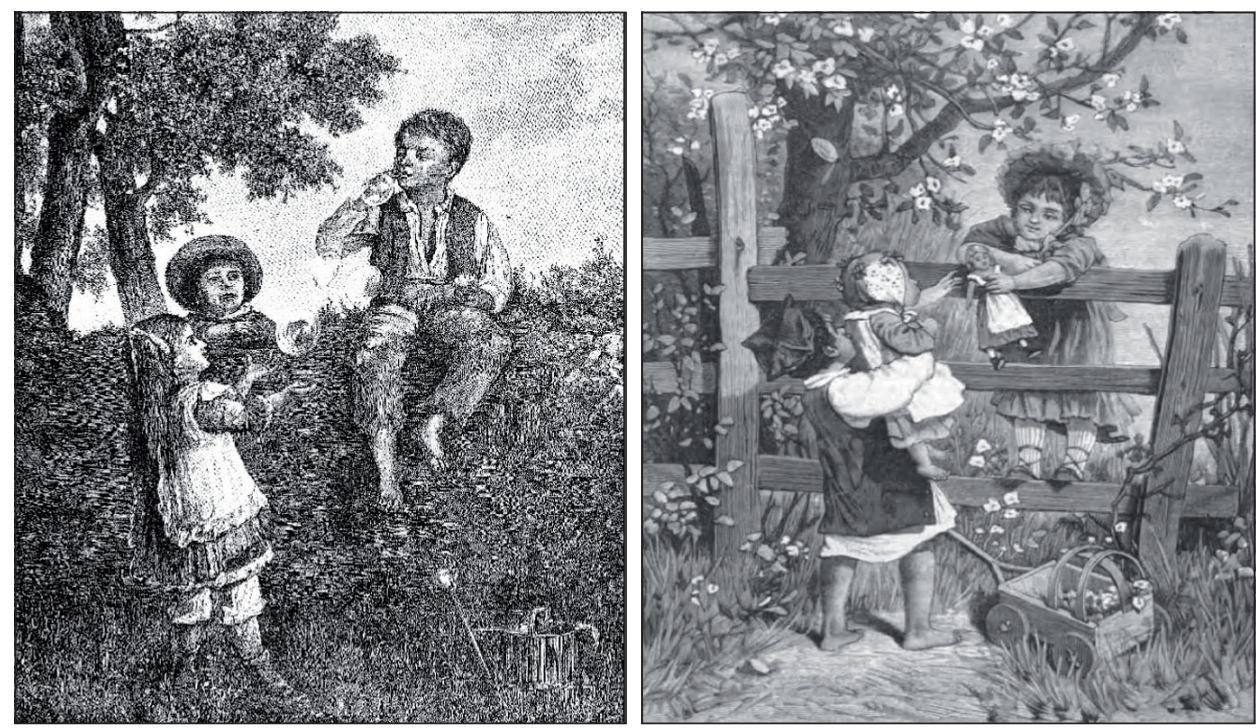

Wspólna zabawa dzieci ziemiańskich i chłopskich

Bańki mydlane, rys. E. Perle, ryt. E. Gorazdowski, „Kłosy” 1876, nr 45 (po lewej)

Na płocie, rys. J. Konopacki, „Kłosy” 1885, nr 1054 (po prawej)
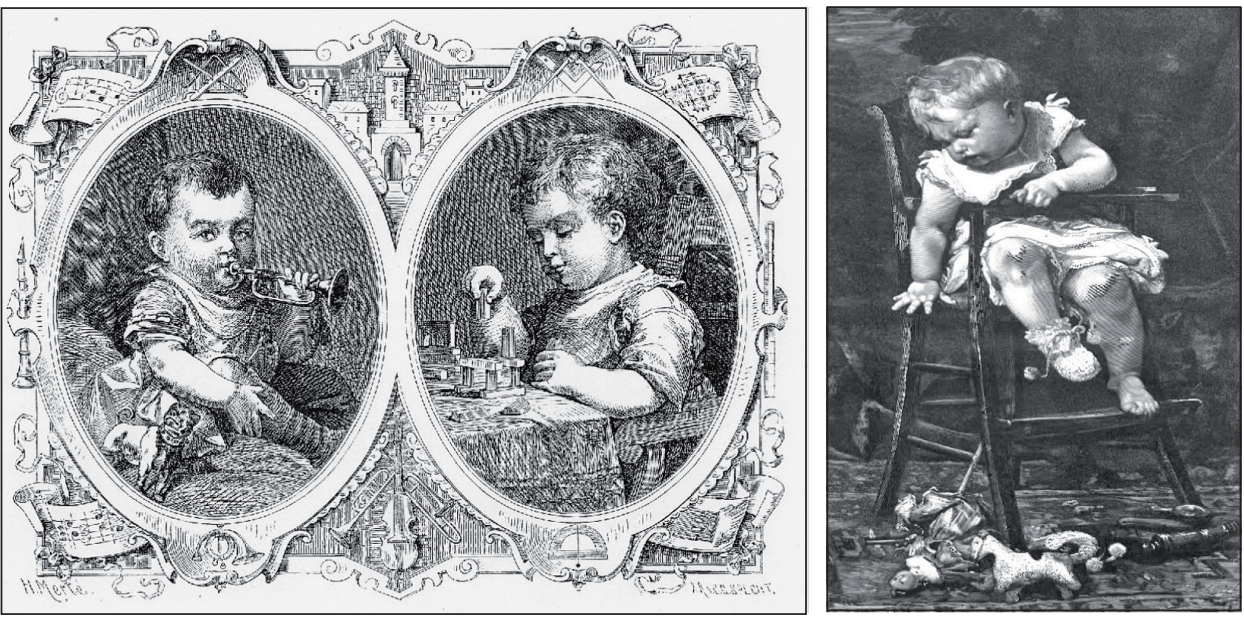

Zabawy najmłodszych dzieci

Wielkie nadzieje (z albumu pociech rodzinnych), „Biesiada Literacka” 1878, nr 120 (po lewej) Męki Tantala. Rysunek z obrazu T. Lobrichona, „Tygodnik Ilustrowany” 1890, nr 50 (po prawej) 
ci robotnicze stosunkowo wcześnie podejmowały różnorodne prace, by zasilić skromny rodzinny budżet.

Od wieku dziecka zależne też było pozostawiane przez dorosłych pole swobody. Zabawy najmłodszych dzieci, wymagających stałego dozoru, w możnych rodzinach nadzorowane i organizowane były często przez piastunki czy bony, choć i starsze z dzieci także często ograniczane były przez ich nadopiekuńczość. W rodzinach chłopskich dorośli, zajęci pracą na gospodarstwie i na roli, nie poświęcali czasu na nadzór zabaw dziecinnych. Dzieci starsze często zajmowały się młodszymi, które towarzysząc im, często przeszkadzały w zabawach. Bez względu jednak na pochodzenie społeczne dzieci, wraz z wiekiem zwiększał się zakres swobody, który pozwalał na wymyślanie różnorodnych zabaw i realizacje różnorodnych pomysłów.

O sposobie spędzania wolnego czasu i rodzajach wybieranych i preferowanych zabaw decydowała także płeć dziecka. Dziewczęta zwykle wybierały zabawy charakterystyczne dla płci niewieściej, mające związek z pełnieniem przyszłych ról kobiecych i rodzinnych, z wykorzystaniem lalek, domków, serwisów, naczyń. Preferowały zabawy ciche i spokojne, bardziej statyczne, zaś chłopcy często wybierali zabawy ruchowe, pełne ekspresji i zwykle bardziej hałaśliwe.

Oczywisty jest fakt, że dzieci obojga płci, niezależnie od klasy społecznej bawiły się wspólnie. Zabawy takie nie tylko sprzyjały nawiązywaniu kontaktów i rozwojowi społecznemu, ale i kształtowały charaktery najmłodszych. Dziewczęta miały uczyć chłopców delikatności i opiekuńczości, one zaś od rówieśników nabywać miały takich cech, jak męstwo, szybkość, zdecydowanie. Często bywało jednak i tak, że dzieci dzieliły się na grupy według płci i tworzyły sobie odrębne światy zabawy, często dla płci przeciwnej niedostępne.

Przynależność do określonej warstwy społecznej decydowała także o bogactwie i różnorodności zabawek, które dzieci wykorzystywały do zabaw. Zasobność portfela rodziców warunkowała dostęp do zabawek fabrycznych, ich liczby oraz jakości, dlatego też dzieci chłopskie i robotnicze miały ich najmniej, w odróżnieniu od dzieci z możnych warstw społecznych, których rodziców stać było na zakup różnorodnych cacek. Bez względu jednak na poziom materialny rodziny, z której wywodziły się dzieci, wszystkie wykorzystywały do zabaw tzw. zabawki naturalne, czyli różnorodne przedmioty codziennego użytku czy elementy świata przyrody, które pełniły role zabawek i rekwizytów niezbędnych do zabaw. Często, na potrzeby zabaw, proste zabawki wykonywali dzieciom dorośli, a bardziej zdolne manualnie dzieci samodzielnie z różnych materiałów wykonywały sobie lalki, konie, miecze, łuki, proce, żołnierzy, a nawet stroje. Najmłodsi zbierali też guziki, szpulki, piórka, muszelki, nasiona, szyszki, kolekcjonowali kamienie, minerały czy owady, np. motyle i żuki.

Dobór zabawek zależny był od wieku i płci dziecka. Dla najmłodszych były przeznaczone grzechotki, piłeczki z gutaperki, figurki zwierząt. Chłopcy bawili się najczęściej ołowianymi żołnierzami, strzelbami, pistoletami, łukami z tarczami, kolejkami, konikami (na biegunach, na platformach z kółkami, w postaci figurek), warsztatami. Dziewczynki miały swoje ulubione lalki, wózki, mebelki, statki (naczynia), kolorowe paciorki. Nie brakowało też zabawek, którymi bawili się i chłopcy i dziewczynki: gumowych piłek, 
kół do serso, blaszanych kogutków, glinianych ptaszków, trąbek, bębenków, drewnianych klocków, skrzyń budowniczych, loteryjek, figurek zwierzątek gospodarskich, drewnianych wózków itp. Chętnie kupowano też dzieciom książeczki z obrazkami, ilustrowane albumy, bajki, książki do kolorowania, kolorowe ołówki, farby.

\section{Charakterystyka wybranych zabaw i zabawek dziecięcych}

\section{Lalka - ulubiona zabawka dziewczynek}

Ulubionymi zabawkami wszystkich dziewczynek były lalki, które w analizowanym okresie wyobrażały najczęściej miniaturowe panienki lub dorosłe kobiety. Dziewczynki, bawiąc się lalkami, wprawiały się w swoje przyszłe obowiązki, uczyły się pełnienia ról społecznych - roli matki i opiekunki. Naśladowały więc troskliwe mamusie, opiekując się lalkami, stroiły swoje pupilki, urządzały lalczyne domki i pokoiki, przyjęcia dla gości, pełniły role piastunek i nauczycielek. W możnych domach lalki kupowano w sklepach, często mówiące, płaczące, chodzące, z całym dobytkiem - strojów, mebli, serwisów, domów, wózeczków. Dziewczynki z ubogich rodzin także bawiły się lalkami - robiły je sobie często z gałganków lub słomy. Nie były one bez wątpienia tak ładne i strojne jak lalki fabryczne, lecz z pewnością miały jedną ogromną zaletę - pozostawiały zdecydowanie więcej pola dla wyobraźni dziecka i nie tłukły się (lalki fabryczne najczęściej miały porcelanowe głowy, co wymagało od dziewczynek niezwykłej ostrożności podczas zabawy, gdyż każdy upadek groził stłuczeniem). W wielu poradnikach czy artykułach prasowych pisano o znaczeniu zabawy lalką w życiu dziewczynek. W roku 1892 w jednym z poradników dla kobiet czytamy: Z pomiędzy zabawek dziecinnych na pierwszym
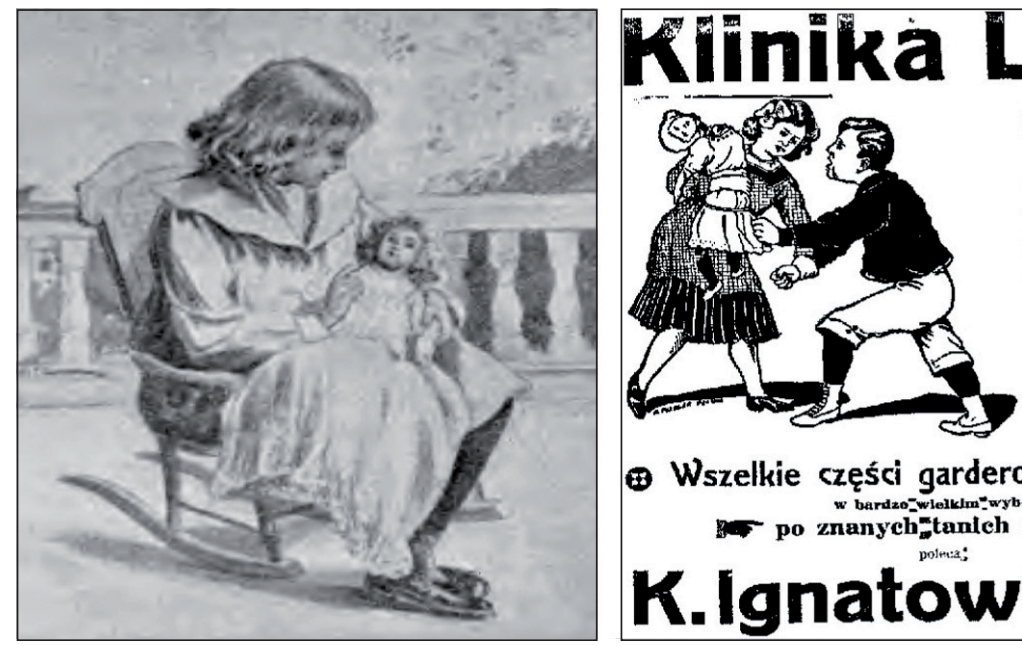

alek

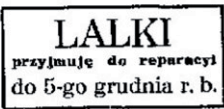

Wszelkie crescl lajek abs

Główki

Rąezki

Nóżki

Oezy

Wlosy

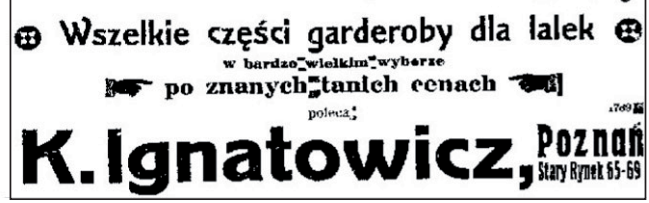

Zabawa lalką, „Moje Pisemko” 1909 nr 26 (po lewej)

Reklama klinki lalek, „Głos Wielkopolanek” 1913, nr 45 (po prawej) 
planie należy umieścić lalkę. Niewinna ta zabawka jest najbardziej odpowiednia i najlepiej sprzyja rozwinięciu się tego usposobienia dziewczynki, które się trwale później ujawnia $w$ catym życiu kobiety. Wdzięczne i niekiedy wysoce zabawne pieszczoty dziewczynki z lalka, jej dtugie gawędy z ulubiona istotka, ubieranie i rozbieranie, kapanie i usypianie $i$ karmienie - wszystko razem wzięte znakomicie łagodzi i uspokaja nadmierne i gwałtowne parcie sity rozwojowej duszy dziecięcia. Niezależnie jednak od tego, wspomniana zabawka posiada jeszcze inne, o wiele głębsze znaczenie [...] wytwarza się to ogólne usposobienie duchowe, które później występuje $w$ tak szlachetnej formie jako miłość macierzyńska i rozwijaja się takie zalety jak czujność, tagodność oraz pieczołowitość i roztropność. A zatem z lekarskiego punktu widzenia bawienie się lalka należy uważać za znakomity środek wychowawczy, który doskonale sprzyja szybkiemu rozwojowi duchowemu dziewczynki ${ }^{6}$.

\section{Konik - ulubiona zabawka chłopców}

Tak jak dla dziewczynek ulubionymi zabawkami były lalki, tak wśród zabawek dla chłopców prym wiodły koniki. W analizowanym okresie popularne były koniki na bujanych płozach, na platformach (często z kołami), na których mali jeźdźcy mogli siadać. Niezwykle popularne były także koniki - a najczęściej głowy konika na kiju, które dziec-
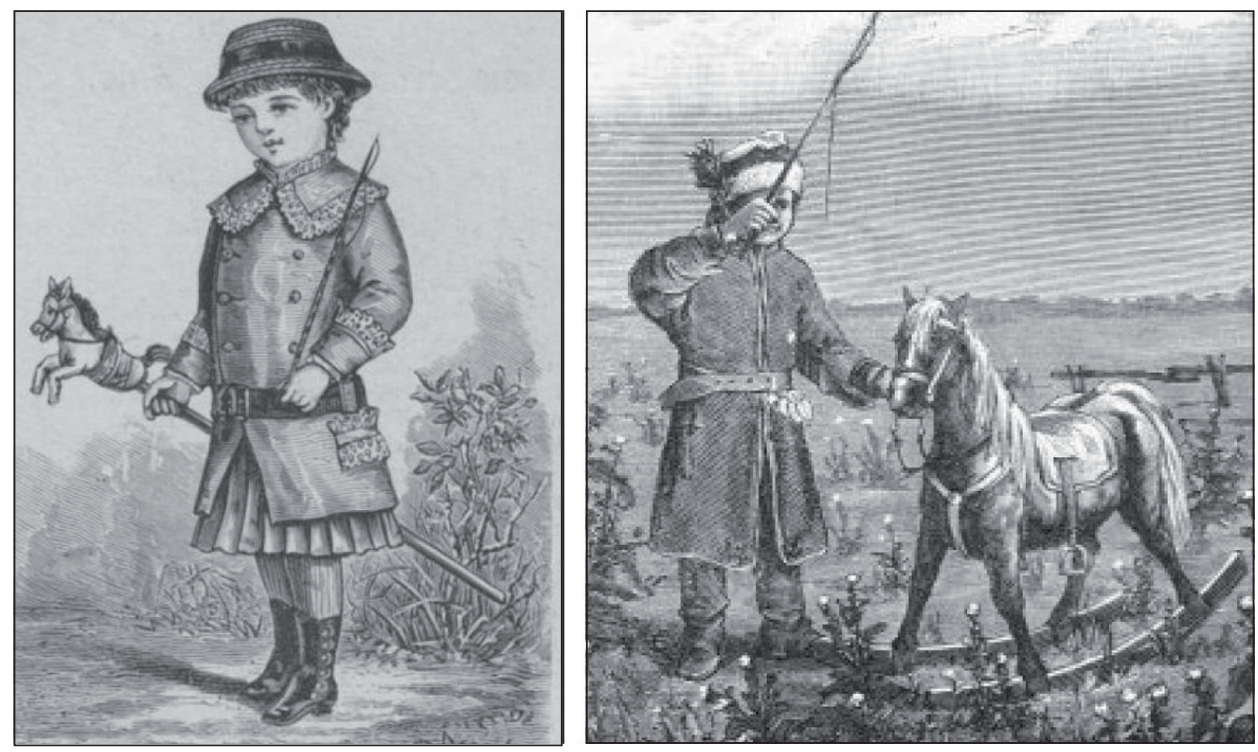

Zabawy konikiem na kiju i płozach oraz biczykiem, „Mody Paryzkie” 1882, nr 6 (po lewej)

${ }^{6}$ Życie kobiety. Listy o higienie kobiecego organizmu. Przez dr. A. Bagińskiego z najnowszego wydania niemieckiego przełożyli Ad. W i Ed. G., Warszawa 1892, s. 8-9. 
ko wkładało pomiędzy nogi i naśladowało jazdę na wierzchowcu. Koniki były najczęściej drewniane, bogatsze wersje pokrywane były skórą, bywało, że z włosiem, miały piękne grzywy i ogony, siodło i uprząż. Chłopcom ubogim za konika służył często zwykły patyk.

Obok koników na kijach i bujanych płozach w sklepach dostępne były figurki koników w różnych rozmiarach, bywało, że z zagrodami, wozami, powozami. Dzieci chłopskie często bawiły się konikami wystruganymi z drewna przez dziadków czy ojców lub wykonanymi samodzielnie. Do zabawy konikiem nie mogło zabraknąć biczyka, którym chłopcy mogli poganiać swojego rumaka. We wspomnieniach Ignacego Jana Paderewskiego znajdujemy fragment opisujący zabawy ulubionym konikiem, wykonanym w domu, wspólnie z siostrą: [...] bytem rycerzem dosiadajacym konia-rumaka, na którym wyruszałem po zwycięstwa. Za rumaka stużyt mi dtugi kij, na którego końcu Antonina umieszczała torbę wypetniona różnymi starymi szmatami, co miało wyobrażać końska głowe - nawet uszy tam byty [...] Na tym wspaniatym rumaku hasatem po całym domu, staczajac wyimaginowane boje $e^{7}$.

Choć w swoim skarbczyku z zabawkami konika posiadał niemal każdy chłopiec, zaś dorośli tę właśnie zabawkę kupowali maluchom bardzo często, to pewnie wielu nie miało pojęcia, że mogła być ona niebezpieczna dla użytkowników. Jeden z lekarzy przestrzegał rodziców i opiekunów dzieci: Do szkodliwych zabawek dziecinnych należa konie na biegunach $i$ laski do jeżḋenia, jak to mówia dziatki: na koniu. Jedno i drugie drażni narzady ptciowe przez laskotanie lub ocieranie podczas ruchu tego jeżḋenia, z której to przyczyny układ płciowy za wcześnie się rozwija, co na przyszłość miewa doniosłe skutki ${ }^{8}$.

\section{Skrzynie budowlane - dla wszechstronnego rozwoju dzieci}

W wielu poradnikach pedagogicznych analizowanego okresu czytamy, że dobra zabawka powinna nie tylko bawić, zajmować czas, ale i rozwijać wiele sfer dziecka. Pożądane były takie zabawki, które przez zabawę uczą i rozwijają intelekt, logiczne myślenie, wyobraźnię, kreatywność. Warunek ten z pewnością spełniały klocki - cegiełki, z których można było budować różnorodne budowle i fortece - uczyły one wyobraźni przestrzennej, dawały wiele możliwości rozwiązań i na długo zajmowały dzieci. Tak pisał o znaczeniu zabawy klockami jeden z czołowych publicystów pedagogicznych drugiej połowy XIX wieku, Henryk Wernic: Tak to dzieci $w$ zabawie rozszerzaja zakres swych pojęć, wyjaśniaja je i utrwalają. Tak to zabawa wprawia w ruch $i$ władze myślenia i przyzwyczaja do czynności umystowej. Teraz już i pudetko architektoniczne nie będzie dla nich zbiorem prostych kawałków z drzewa, lecz pożadanym materiałem, za pomoca któ-

\footnotetext{
7 I. J. Paderewski, Pamiętniki, spisała M. Lawton, Warszawa 1982, s. 33-34.

${ }^{8}$ Dyjetetyka dzieci oparta na wskazówkach przyrody. Przewodnik $w$ zdrowem pielegnowaniu dzieci od przyjścia na świat aż do dojrzenia skreślony przez przyjaciela dzieci (lekarza - prof. E. Madeyskiego), Lwów 1869 , s. 141.
} 
Na grafice: reklama skrzynek budowlanych Richtera, w: Kalendarz krakowski Józefa Czecha na rok 1908

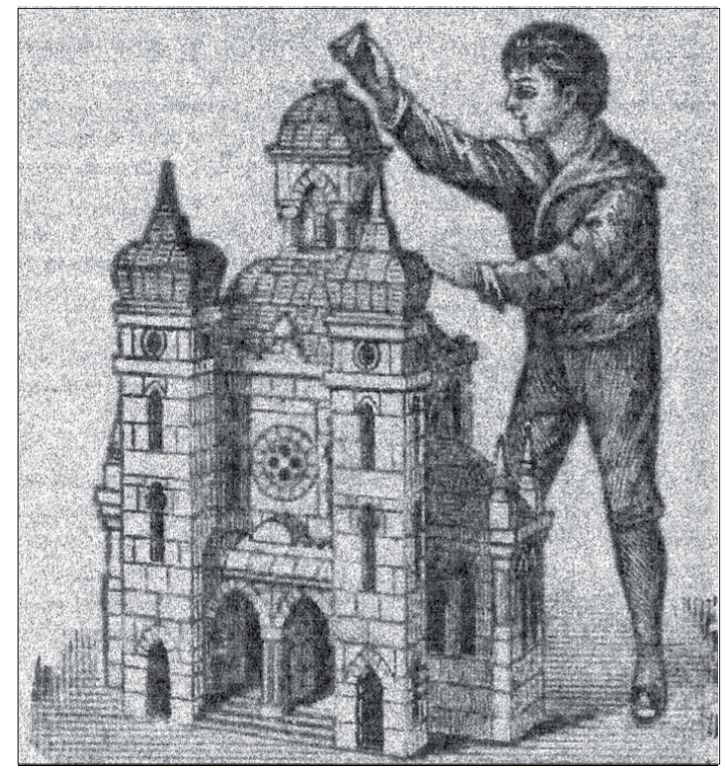

rego wznosić będa domy i pałace, budować mosty i sypać waty ${ }^{9}$. Dlatego sa klocki budowlane wszelkiej wielkości tak pożądane i wysoko cenione, gdyż pobudzaja $w$ dzieciach zmyst tworzenia. Dziecko zestawia je, rozrzuca, przestawia i buduje a fantazja jego wciaż pracuje $^{10}$ - pisano $\mathrm{w}$ jednym $\mathrm{z}$ poczytnych poradników dla kobiet $\mathrm{w}$ początku XX wieku.

\section{Kiedy nowe zabawki? Reklama dźwignią handlu}

Istotną kwestią pedagogiczną była liczba posiadanych przez dziecko zabawek oraz ich jakość. Dobra zabawka miała być dla dziecka bezpieczna, wykonana z substancji pozbawionych trujących farb barwiących, trwała, bez ostrych krawędzi i drobnych elementów. Pedagodzy sugerowali rodzicom i opiekunom, by nie zarzucali najmłodszych niezliczoną ilością zabawek i cacek, gdyż nie będą one potrafiły docenić faktu ich posiadania i przestaną je szanować. Mniejsza liczba zabawek pozostawiała więcej możliwości dla dziecięcej wyobraźni i nie rozbudzała chęci posiadania, egoizmu, szybkiego nudzenia się i oczekiwania nowości. Jednak - oczywiście w zamożnych rodzinach - zabawki kupowano stosunkowo często, zwykle w sposób nieprzemyślany, bez zwracania uwagi na ich walory kształcące, ulegano kaprysom dziecka i oczywiście modzie - bo i ta miała

\footnotetext{
${ }^{9}$ H. Wernic, Wychowanie dziecka włącznie do lat sześciu, Warszawa 1881, s. 39.

${ }^{10}$ Dr med. Fischer-Duckelmann A., Kobieta lekarka domowa. Podręcznik lekarski do pielęgnowania zdrowia i lecznictwa $w$ rodzinie, ze szczególnym uwzględnieniem chorób kobiecych i dziecięcych, położnictwa i pielęgnowania dzieci. Na polskie przełożyła za zezwoleniem autorki T. Jaroszewska z współudziałem dr. A. Czarnowskiego, Mikołów-Warszawa 1908, s. 771.
} 


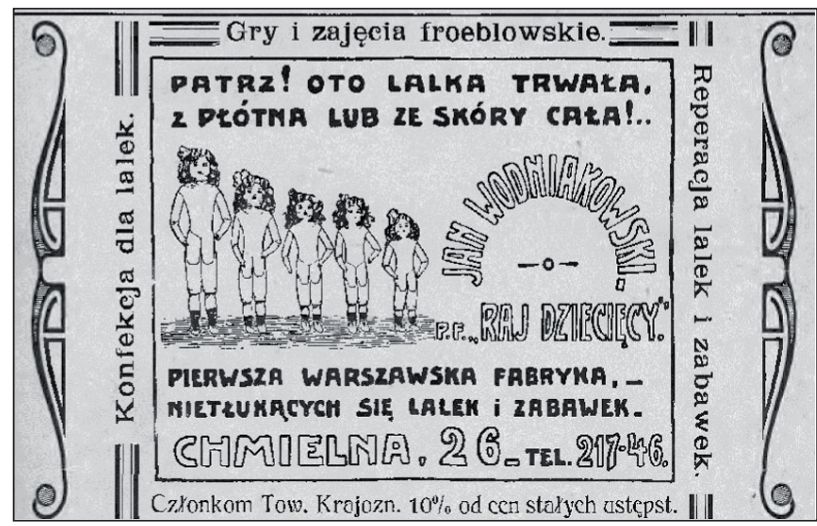

$\mathrm{Na}$ grafice: reklama warszawskiej fabryki lalek i zabawek, „Ziemia” Tygodnik Krajoznawczy Ilustrowany, Warszawa-Lwów 1914, nr 23)

ogromne znaczenie przy podejmowaniu decyzji dotyczących wyboru cacek dla najmłodszych. By zapobiec tej praktyce, pedagodzy sugerowali, że do obdarowywania dziecka zabawkami najlepsze były specjalne okazje - urodziny, imienny czy święta. Szczególnie wiele porad dotyczących zasad wyboru zabawek dziecinnych pojawiało się w okolicach Bożego Narodzenia, kiedy to sklepy kusiły rodziców ogromnym wyborem zabawek produkcji krajowej i zagranicznej. W grudniu do trosk rodzicielskich przybywa jeszcze i ta, co swym pieszczochom dać na Gwiazdkę. Jaka zabawka zajmie, zbawi, pouczy? ${ }^{11}$. Odpowiedź na to pytanie rodzice mogli odnaleźć w zamieszczanych w prasie, książkach czy kalendarzach reklamach, których z mijającymi dekadami drugiej połowy XIX wieku pojawiało się coraz więcej. Sklepy i składy ogłaszały swoją bogatą ofertę sprzedaży gwiazdkowej towarów dla najmłodszych, zapewniając o doskonałej ich jakości, marce czy najlepszej cenie, zamieszczając niejednokrotnie ilustracje swoich towarów. Choć reklamy te adresowane były do osób dorosłych, to dziecko, widząc taką reklamę w magazynie dla rodziców z pewnością łatwiej i szybciej układało listę prezentów pod choinkę. I można przypuszczać, że przy wyborze zabawek więcej rodziców korzystało z chwytliwych ogłoszeń reklamowych niż ze wskazówek publicystów pedagogicznych zamieszczanych na łamach prasy czy poradników. Analizując materiały źródłowe, czy to pisane czy ikonograficzne, stwierdzić można, że dzieci najczęściej bawiły się piłkami, lakami, klockami, trąbkami, bębenkami, konikami, biczykami, obręczami, kolejkami, figurkami zwierząt. Nie brakowało także zabawek mechanicznych, poruszających się, a nawet puszczającymi parę czy wydających dźwięki. Często sprowadzano je z zagranicy i sprzedawano za sumy, na które stać było jedynie najbogatszych.

\section{Strój do zabawy}

By zabawa sprawiała wiele radości, nie powinna być skrępowana niewygodnym i drogim strojem. Niestety, w możnych domach nie przestrzegano często zasady, że wy-

11 R. Pachucka, Zabawki wyrobu ludowego, „Dziecko” 1913, nr 9, s. 536. 

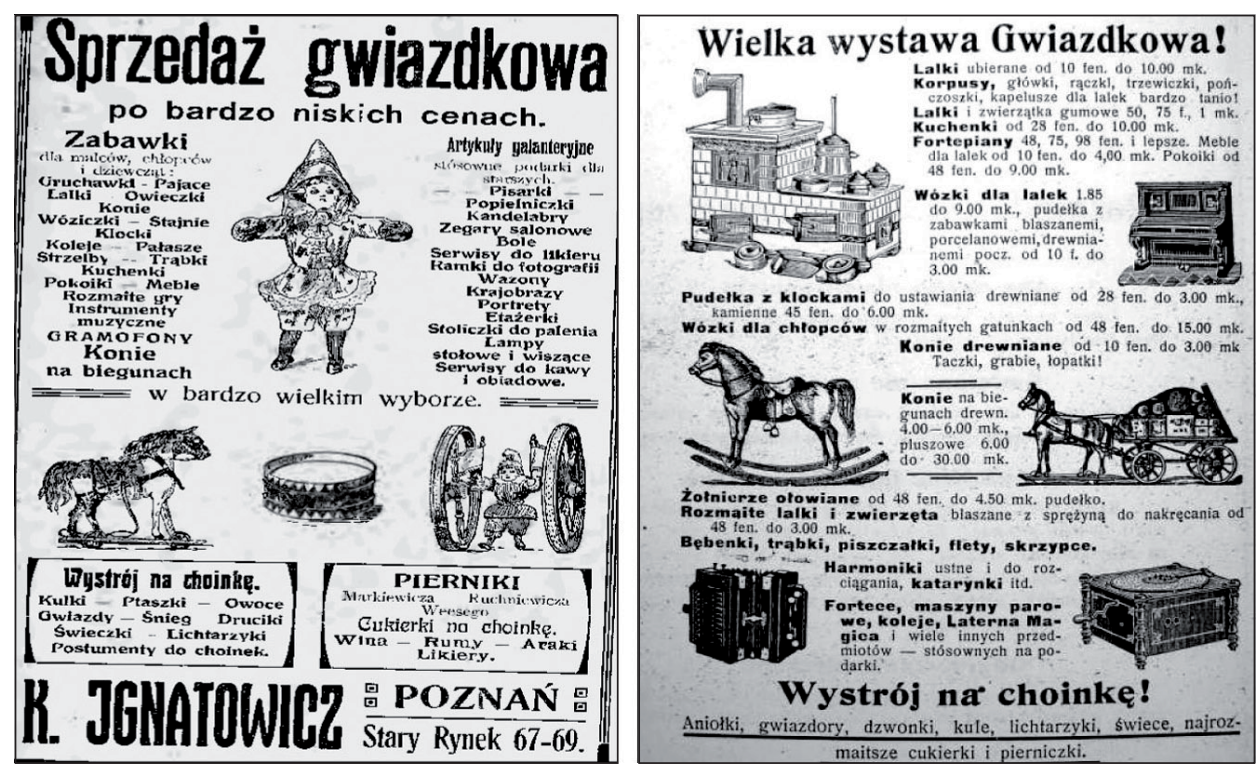

Reklama sprzedaży gwiazdkowej zabawek, „Straż”. Miesięcznik Związku Towarzystw Straż, Poznań 1911, nr 1 (po lewej)

Praktyczna kuchnia. Tanie $i$ tatwe przepisy wypróbowane $i$ spisane dla wnuczek przez Babule, Poznań 1903 (dodatek reklamowy) (po prawej)

Na grafice: Ubranie reformowe, w: A. Fischer-Dückelmann, Zabawy dziecięce, w: Kobieta lekarka domowa, przeł. T. Jaroszewska, A. Czarnowski, Mikołów - Warszawa 1908 (u dołu)

goda powinna iść przed modą i strojono dzieci w ubiory podług najnowszych, głównie francuskich żurnali mód. Czasopisma poświęcone modzie (których na terenie ziem polskich nie brakowało w badanym okresie) niemal w każdym numerze publikowały ryciny prezentujące stroje dla dzieci w różnym wieku, prezentując najmłodszych zwykle podczaj wesołej zabawy, utwierdzając tym samym odbiorczynie pism w przekonaniu, że do niej się właśnie nadają. Stroje takie-jak widać na prezentowanych rycinach - były być może estetyczne i ładne, ale liczne zdobienia, koronki, kokardki, falbanki, guziczki, halki itp. z pewnością nie ułatwiały swobodnej zabawy. Publicyści, autorzy poradników wychowawczych, głównie pedagodzy i higieniści często apelowali do rodziców, by stroje dziecięce były adekwatne do wieku dziecka, temperatury otoczenia, by nie były przesadnie strojne, a co najważniejsze, by nigdzie nie uciskały i nie krępowały ruchów.

W jednym poradników z początku XX w. czytamy: Dla dzieci moda żadna ma nie istnieć, gdyż pro-

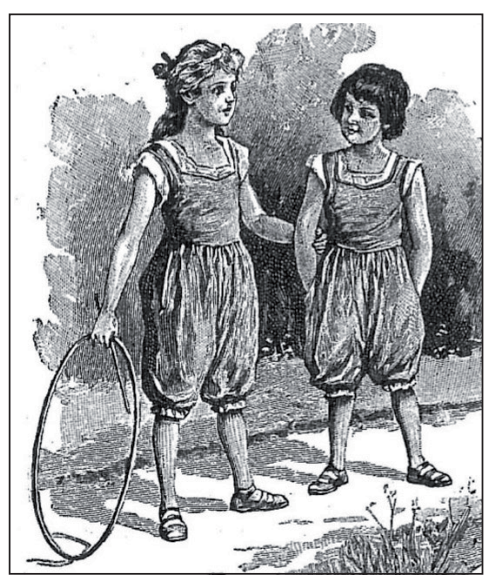


wadzi ona już we wczesnej młodości do chęci strojenia się $i$ do próżności [...] nie należy modnisiowania owego u dzieci cierpieć, bo ponieważ jest ono jak największa przeszkoda dla ich zabaw. Bo czyż nie często można zauważyć, jak wystrojone dzieci przy zabawie bywaja napominane przez dozorujace osoby, aby ubrania nie podusity i pobrudzity i jak się je taje, gdy w swym wesotym uniesieniu zapominaja, iż nie maja być wesotymi $i$ rozkosznymi małymi stworzeniami, lecz matpiatkami mody, które z miłości dla swych pięknych strojów mają się nudzić? ${ }^{12}$. Z upływem dziesięcioleci moda się zmieniała, ubiory codzienne stawały się mniej strojne, krój stawał się bardziej swobodny, zaś początek XX w. przyniósł reformę odzieży i sprawił, że stroje stały się lżejsze, luźniejsze i z pewnością wygodniejsze podczas dziecięcych swawoli. Co równie istotne, już w pierwszych dekadach drugiej połowy XIX w. powstawać zaczęły projekty ubrań do gier i zabaw oraz sportów dziecięcych, które przybrały formę wygodnych kostiumów gimnastycznych.

\section{Kinderbale - baliki dziecięce}

Nieodłącznym elementem rozrywki w życiu dzieci, niezależnie z jakiej warstwy społecznej pochodziły, była muzyka. W każdej niemal rodzinie grywano na instrumentach, śpiewano i tańczono. W możnych rodzinach, najczęściej w okresie karnawału, ale zdarzało się, że i w innych okresach roku (np. z okazji urodzin czy imienin, świąt) organizowano baliki i przyjęcia dla dzieci, zwane też kinderbalami. Brały w nich udział dzieci w wieku od kilku do kilkunastu lat. Na kinderbale często zapraszano gości z sąsiedztwa, zaś najmłodsi mieli okazję pochwalić się swoimi umiejętnościami tanecznymi, znajomością etykiety towarzyskiej, nawiązać znajomości z rówieśnikami ze swojego stanu. Na balu, szczególnie karnawałowym, obowiązywały często przebrania, zaś pomysłów i inspiracji do ich wykonania dostarczały np. czasopisma poświęcone modom i strojom. Dzieci, pięknie wystrojone, z gracją i klasą naśladowały zachowania dorosłych podczas przyjęć i bali. Pedagodzy i moraliści krytykowali ten sposób spędzania czasu przez dzieci, ostrzegając, że bale mogły stać się przyczyną i ,zarodem niebezpiecznych namiętności ${ }^{13}$ ", w dziewczynkach budząc próżność, chęć podobania się płci przeciwnej, a w chłopcach przedwczesną zmysłowość.

W pamiętniku Zofii z Rodowiczów Iwanickiej znajdujemy fragment poświęcony takim tanecznym wieczorkom: Rodzice nasi dobrze wiedzieli, że nauke trzeba przeplątać rozrywka $i$ wypoczynkiem. Toteż od najmłodszego dzieciństwa uczyli nas tańczyć [...] i często urządzali wieczorki taneczne pomiędzy znajomymi [...] Święta Bożego Narodzenia, zapusty, święta Wielkiejnocy mijały gwarno i wesoło na ciagłych potańcówkach, matka nasza i pani Maria Malikiewiczowa, grajac na fortepianie stanowity stała, niezawodna orkiestre, a my hasaliśmy z całej duszy podczas beztroskich lat naszego dzieciń-

\footnotetext{
${ }^{12}$ Dr med. J. Springer, Lekarka domowa. Złota księga kobieca ku oświetlaniu i pouczeniu dla zdrowych i chorych o najważniejszych kwestiach nauki zdrowia i lecznictwa, Wieleń, po 1900, s. 607.

${ }^{13}$ Matka chrześcijańska ukochanym dziatkom. Według najcelniejszych mistrzów ułożył A. Morawski, Kraków 1882, s. 198.
} 

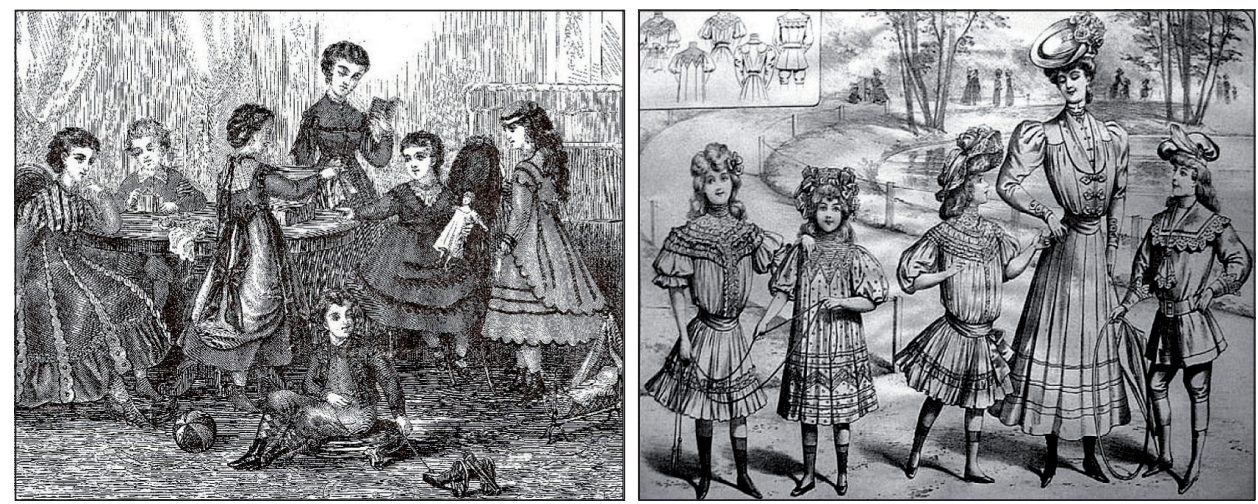

Ubrania dziecinne od 3 do 13 lat, „Tygodnik Mód” 1868, nr 27 (po lewej)

Stroje dla dziewczynek od 8 do 12 lat, „Tygodnik Mód” 1885 (po prawej)

$s t w a^{14}$. Lecz bywały i takie kinderbale, podczas których do tańca przygrywała nie matka czy nauczycielka, ale prawdziwa orkiestra, na których dzieci, ubrane w stroje według najnowszych żurnali mód jadły i piły sprowadzane z zagranicy frykasy, a zabawa przeciągała się długo w noc. Oczywiście były one domeną najmożniejszych warstw społecznych. Dużo częstsze bywały sytuacje, że tańczono także w mniejszym gronie, składającym się z rodziców i dzieci, rezydentów czy gości dworu, zaś salą balową była bawialnia czy nawet korytarz. Najmłodsi sami chętnie organizowali zabawy w bal, naśladując przy tym dorosłych.
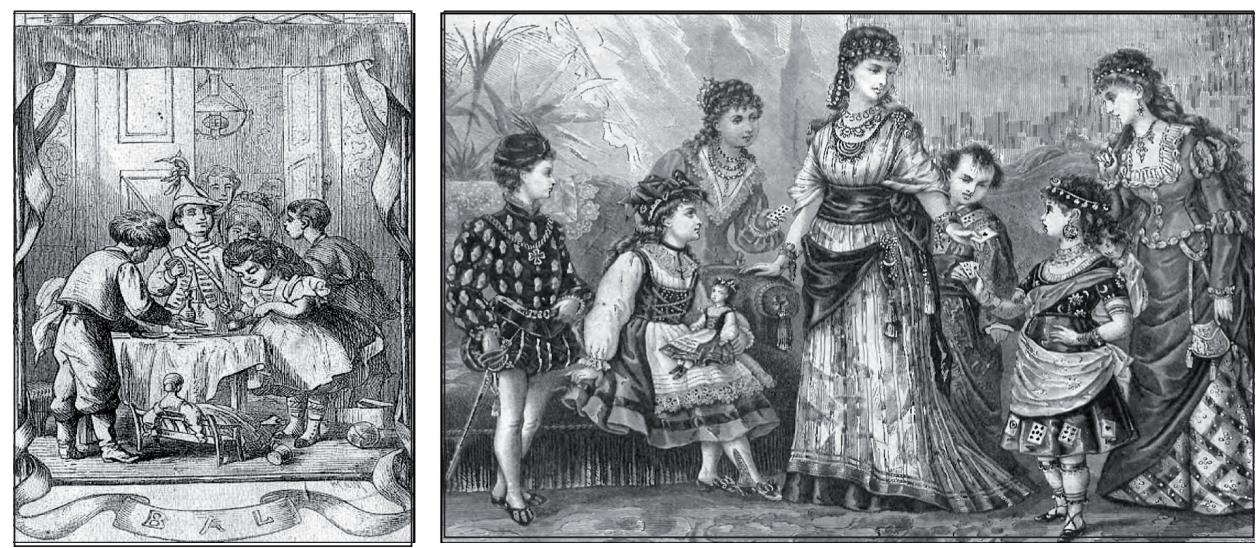

Zabawa w bal, Dzień grzecznego Władzia w rymowanych ustępach opowiedziany dziatwie z dodatkiem różnych wierszyków przez Jana Chęcińskiego, Warszawa 1867 (po lewej)

Wzory kostiumów balowych dla dzieci i młodzieży, „Bluszcz” 1876, nr 45 (po prawej)

${ }^{14}$ Z. z Rodowiczów Iwanicka, Pamiętnik, w: W. Rodowicz, S. Rodowiczowa, Z. z Rodowiczów Iwanicka, Tryptyk rodzinny. Dzieje rodziny Rodowiczów, Warszawa 1999, s. 74. 
Dzieci chłopskie czy robotnicze oczywiście z kinderbalach nie uczestniczyły, jednak zabawy z wykorzystaniem muzyki, śpiewu i tańca były i w tych warstwach często praktykowane. Sposobem na uprzyjemnienie czasu były wspólne śpiewy, gra na instrumentach (piszczałkach, skrzypcach) czy tańce. Często na wsi na pastwiskach urządzano „wesela", odbywające się na wzór prawdziwych, wiejskich wesel. Najmłodsi bywali też zabierani przez rodziców na wesela, zabawy w karczmie, czy spotkania w chatach, podczas których muzykowanie było główną formą rozrywki.

\section{Gry i zabawy ruchowe}

Druga połowa XIX w., wraz mijającymi dekadami przynosi coraz większe zainteresowanie rozwojem fizycznym dzieci. Na rynku wydawniczym pojawiają się poradniki poświęcone ruchowi fizycznemu, grom i zabawom, gimnastyce, uprawianiu ćwiczeń, które zalecano praktykować od najmłodszych lat. Niestety, zachowania tego typu w większości rodzin nie były popularne, ale w niektórych domach, w których rodzice dbali o rozwój fizyczny dzieci, stosowano się do zaleceń higienistów, pedagogów i lekarzy. W obszernych pokojach dziecinnych zawieszano nie tylko popularne huśtawki, ale dodatkowo także przyrządy do ćwiczeń fizycznych - trapez, kółka, drabinki itp. Dzięki gimnastyce pokojowej dzieci mogły nawet podczas niepogody zażywać ruchu. Kazimierz Andrzej Jaworski opisywał ulubione zabawy na przyrządach, które rodzice zamontowali w jego pokoju - [...] zapamiętawszy niektóre rodzaje ćwiczeń akrobatycznych, stopniowo na mała skale zaczałem je stosować. Podciagałem się więc szybko na trapez, później huśtałem się na nim trzymając się sznurka jedna ręka, a potem już nie trzymając się żadna, robiłem młynek kręcąc się zgięta w kolanie noga wokół osi poprzeczki, zawisatem głowa $w$ dół na obu nogach $i$ na jednej. Robiłem też $i$ inne tak zwane sztuczki. Dla bez-
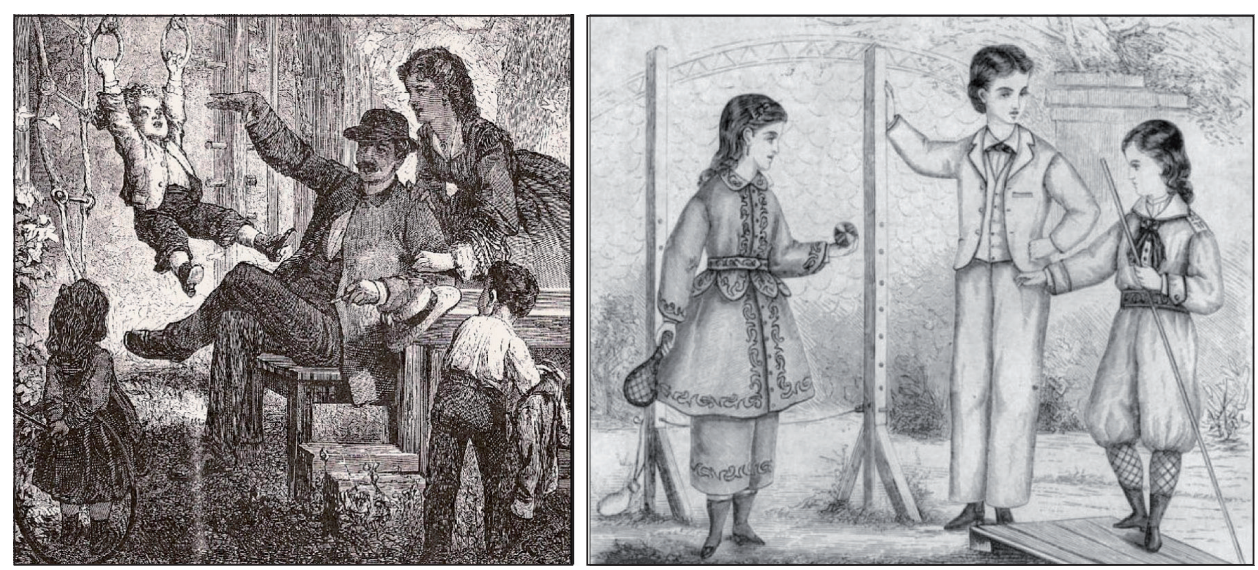

Z życia dworu wiejskiego. Gimnastyka pokojowa, „Kłosy” 1893, nr 423 (po lewej)

Ubrania do gimnastyki dla dziewczynek i chłopców od 6 do 12 lat, „Bluszcz” 1870, nr 24 (po prawej) 


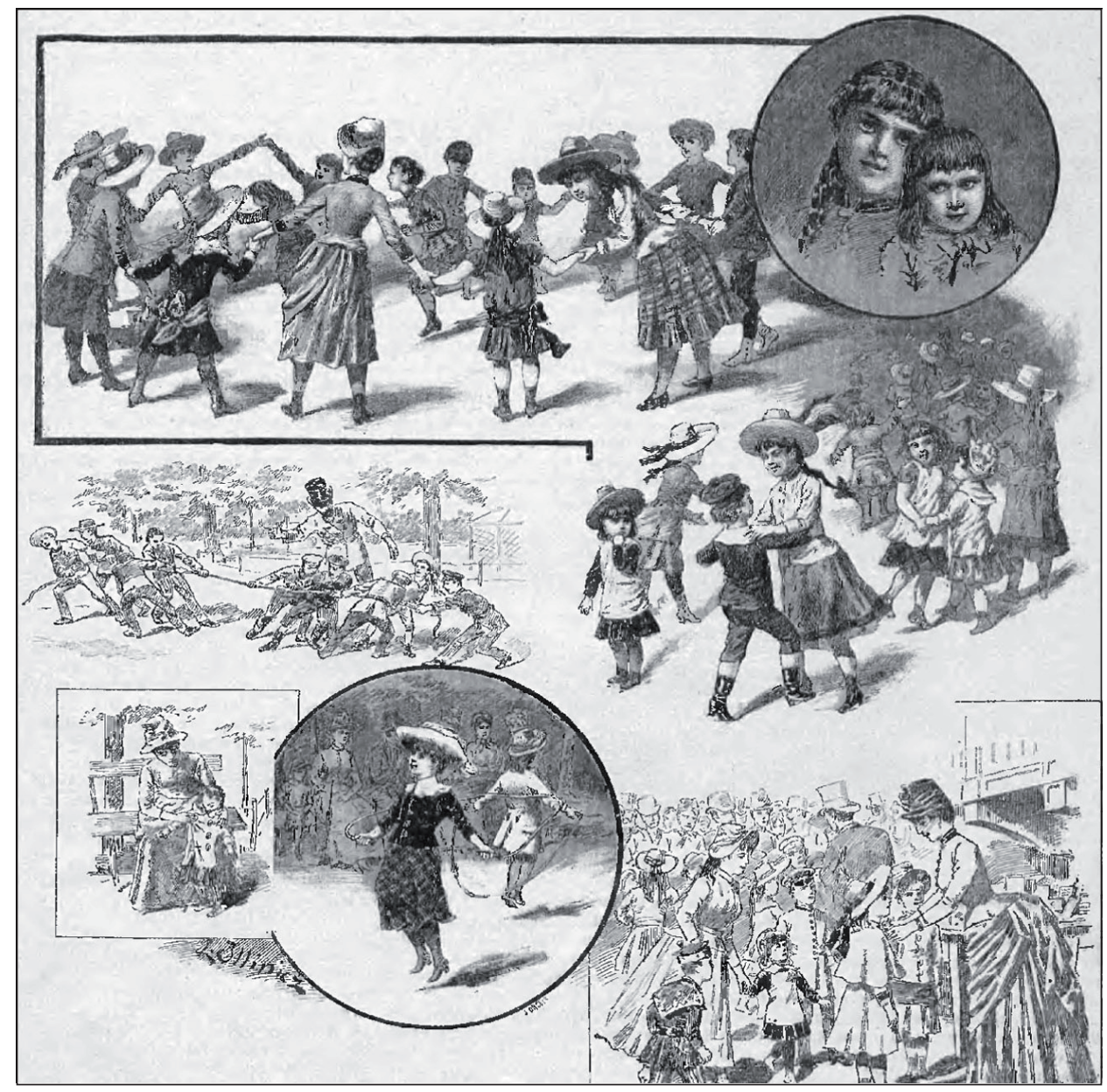

Zabawy ruchowe $w$ warszawskim ogrodzie dziecięcym $w$ Zwierzyńcu, „Tygodnik Ilustrowany” 1886, nr 185

pieczeństwa nad trapezem rozkładali mi materac, ale $i$ tak nasi znajomi, widzac czasami moje popisy, chwytali się za głowe [...] Ale rodzice jakoś wierzyli w moje sity, ojciec uważat, że $w$ ten sposób ćwiczę mięśnie $i$ wyrabiam $w$ sobie odwagę ${ }^{15}$.

Przy niektórych kamienicach, willach, dworach czy pałacach, urządzano także specjalne place do ćwiczeń fizycznych w ogrodach czy parkach, nazywane potocznie gimnastykami. Instalowano tam huśtawki, trapezy, specjalne drabinki, liny, kołobiegi. Urządzenia do ćwiczeń służyły najmłodszym nie tylko do ćwiczeń, ale także do zabaw

15 K. A. Jaworski, Wywoływanie cieni, Lublin 1968, s. 26. 
ruchowych i sprawiały wiele radości. Dzieciom ubogim za urządzenia te służyły parkany, płoty, drzewa, a nawet dachy chat czy wiejskich zabudowań.

Ruch fizyczny szczególnie istotny był dla tych dzieci, które rozpoczęły już naukę i mniej czasu miały na swobodne zabawy. Ówcześni pedagodzy i higieniści nieustannie apelowali do rodziców, by organizowali dzieciom niezbędne zajęcia ruchowe w formie regularnych spacerów, rozmaitych gier i zabaw. Ich dobór oczywiście należało uzależnić od wieku, płci, temperamentu, stanu zdrowia i poziomu rozwoju dziecka. Do najpopularniejszych zabaw dziecięcych odbywających się w ciepłe dni na wolnym powietrzu należały w analizowanym okresie, np. kot i myszka, krogulec i kurczęta, kot zawieszony, pokój do wynajęcia, rzemieślnicy, wąż, skradziono mi płótno, bociany i żabki, ślepe babki, trzeciak, dzień i noc, a także tzw. gry z przyrządami, np. obrączki, wolant, strzelanie z łuku, confetti, billbokiet, palant, gra w piłkę, serso, kręgle. Zalecano też kąpiele $\mathrm{w}$ rzece lub jeziorze, pływanie, wiosłowanie, przechadzki, jazdę konną, jazdę na kole (rowerze), zajęcia rolnicze, pomoc w gospodarstwie, kilkudniowe piesze wycieczki i wyprawy w góry. Zimą proponowano dzieciom jazdę na sankach, łyżwach, nartach, zabawy śnieżne, a przede wszystkim systematyczne spacery. Ośrodkiem popularyzacji ruchu fizycznego wśród dzieci i młodzieży była Galicja, gdzie powstało najwięcej podręczników i poradników z dziedziny wychowania fizycznego, gier i zabaw ruchowych zarówno na powietrzu, jak i pokojowych. Powstawać zaczęły także pierwsze towarzystwa, szkoły i ogrody gimnastyczne, będące wzorem i inspiracją dla pozostałych zaborów. We wspomnieniach pamiętnikarskich odnaleźć można wzmianki, że dzieci, choć dopiero pod koniec XIX w., uczęszczały na gry i zabawy ruchowe do specjalnych ogrodów, zakładów i towarzystw, zajmujących się rozwojem fizycznym dzieci. W ramach zajęć były nie tylko ćwiczenia ogólnorozwojowe, ale i takie z wykorzystaniem specjalnego sprzętu, jak wspinanie na drabinki, zwisy, biegi po ławeczkach, wdrapywanie po linach oraz liczne i różnorodne zabawy ruchowe.

\section{Pasionka - czas pracy i zabawy dzieci chłopskich}

Dzieciństwo na wsi zdecydowanie odbiegało od dzieciństwa dzieci z zamożnych warstw społecznych analizowanego okresu. Dzieci od najmłodszych lat traktowane były jako kolejna para rąk do pracy, włączane w prace gospodarskie, miały wyznaczone konkretne obowiązki i zadania. W momencie podjęcia pierwszej pracy - najczęściej pasionki, dzieci miały często około 4-5 lat. Nie znaczy to jednak, że w tym okresie kończył się czas swobody i zabawy. Wręcz przeciwnie, pasionka, czyli wypasanie drobiu, bydła czy koni stawała się czasem, w którym najmłodsi spotykali się z rówieśnikami i wymyślali najróżniejsze gry i zabawy, by umilić sobie całodzienny pobyt na pastwisku. A że pasionka trwała często kilka lat, często tak długo, aż dziecko nie nadawało się do cięższych prac gospodarskich, tworzyły się ,pastwiskowe społeczności zabawowe”, które często zaskakiwały bogactwem i różnorodnością pomysłów na zabawy. Pastuszkowie często bawili się wspólnie, bez względu na płeć czy wiek, młodsi pozostawali pod opieką starszych, lecz bywało i tak, że tworzyły się grupy czy to dziewcząt, czy chłopców, dzieci 
młodszych i starszych, a każda z grup miała swoje sposoby na umilanie sobie czasu. Chłopcy bawili się w wojny i bitwy, wyścigi, wspinali się po drzewach, siłowali się, urządzali zawody w wykradaniu ptasich jaj z gniazd, rzucaniu kamieniami lub szyszkami do celu. Dziewczynki często zbierały kwiaty, plotły wianki, kapelusze ze słomy czy sitowia, śpiewały. Wszystkie dzieci uczestniczyły w: grach w ganianego, chowanego, muzykowaniu i tańcach. Układały piosenki czy rymowanki towarzyszące zabawom. Chętnie brały udział w zabawach ruchowych, do których same obmyślały reguły lub których uczyli ich dorośli. Często zabawy tak pochłaniały uczestników, że zwierzęta wchodziły w szkodę. Jako rekwizyty do zabaw dzieci wykorzystywały najczęściej to, co znalazły na pastwisku i w jego okolicy - piasek, błoto, gałęzie, kije, kamienie, szyszki, owoce, pnie drzew, liście itp. Bywało, że samodzielnie wykonywały zabawki z kawałków kory czy drewna, głównie figurki

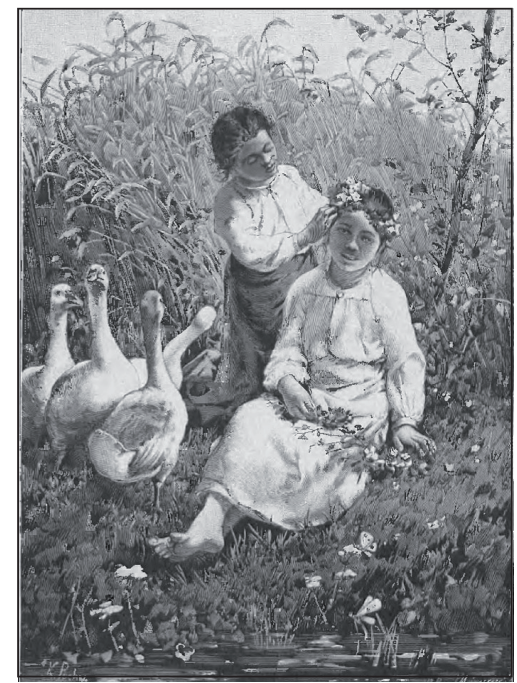

Na grafice - zabawa dziewcząt w wianki podczas pasania gęsi, $W$ niedziele, Rys. K. Pochwalskiego, „Tygodnik Ilustrowany" 1886, nr 18 zwierząt, laleczki, łódki, strzelby i fujarki. W jednym z pamiętników, autorstwa Teodora Kaczyńskiego, pochodzącego z rodziny chłopskiej zamieszkałej w zaborze rosyjskim czytamy: Dobrym pasterzem to ja nie bytem. Zamiast chodzić z batem, żeby odganiać krowy od szkody, to powstawały mi w glowie fantazje: polowania - kawałek zagiętego kija stanowił strzelbe [...] czy zabawa kamieniami, krzemieńcami w gospodarstwo, ustawianiem koni, gołębi czy owiec, albo wykorzystując większy kawałek kija, jeździłem na nim jak na koniu po wymarzonych krainach ${ }^{16}$. Podczas pasionki więc zabawa towarzyszyła wykonywanej pracy i była jej niewątpliwym urozmaiceniem.

\section{W co się bawić? Poradniki i wskazówki do organizacji zabaw}

By pomóc wszystkim tym, którzy stawali przed trudnym zadaniem - czym zająć dzieci w różnym wieku, pisano i wydawano poradniki z zakresu gier i zabaw dla dzieci i młodzieży. Adresowane były one głównie do możnych warstw społecznych. Na stronach tego typu książek dorosłym, którzy zajmowali się organizacją zabaw dziecięcych, a więc rodzicom, bonom czy nauczycielkom podpowiadano, w jaki sposób mogą prowadzić zabawy z dziećmi. Repertuar prezentowanych zabaw był niezwykle bogaty - w poradnikach bowiem można było znaleźć wskazówki do realizacji zajęć w domu, na powietrzu, o każdej porze roku i dnia dla dzieci w różnych przedziałach wiekowych, zarówno

\footnotetext{
${ }^{16}$ T. Kaczyński, Z żóttym kuferkiem. Wspomnienia ludowca i nauczyciela, Warszawa 1987, s. 32-33.
} 


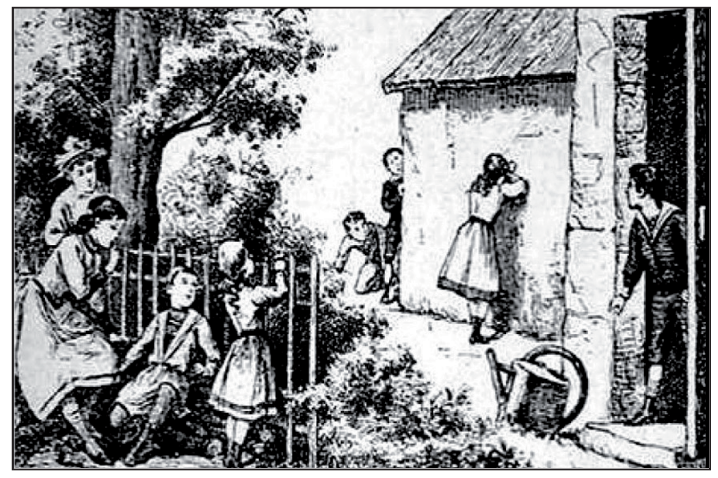

Zabawa w chowanego, w: M. Weryho, Gry i zabawy towarzyskie w pokoju i na dworze, Warszawa 1900

indywidualne, dla jednego dziecka, jak i grupowe, dla kilkorga dzieci. W poradnikach zawierano szereg wskazówek metodycznych, przedstawiając pomysły na zabawy i gry ruchowe, umysłowe, swobodne, bez przyrządów, lub z wykorzystaniem różnych zabawek czy sprzętów. Zabawy zwykle publicyści dzielili zabawy na dwa rodzaje - pokojowe i odbywane na świeżym powietrzu. Wśród nich były zajęcia wymagające przedmiotów i zabawek niezbędnych do gry, lub też takie, w których dzieci wykonywały jakieś czynności bez tzw. przyrządów. Każda z zabaw czy gier była zwykle dokładnie opisana, autorzy wyjaśniali reguły i zasady ich przeprowadzenia, określali warunki niezbędne do realizacji zabawy, wiek i liczbę uczestników, wskazywali na niezbędne pomoce i przyrządy. W niektórych poradnikach wskazywano także na pochodzenie i historię danej zabawy, a jej charakterystykę uzupełniały ilustrujące ją grafiki. Nie brakowało też na rynku wydawniczym pozycji, które wskazywały, jak wykonywać w warunkach domowych, przy użyciu powszechnie dostępnych materiałów i sprzętów proste doświadczenia i sztuczki magiczne. Zabawy wykonywane z pomocą tego typu wydawnictw, pod okiem opiekuna, z pewnością nie tylko bawiły, ale miały też wymiar kształcący - dziecko poznawało podstawowe prawa fizyki, chemii czy innych nauk ${ }^{17}$.

17 Zob. np.: Gry i zabawki dla dzieci. Naśladowane z francuskiego. Z dziesięcią rycinami kolorowanemi, Warszawa 1851; A. Głębocki, Wzory zabawek dla dzieci do wycinania z papieru, Warszawa 1876; Ł. Gołębiowski, Gry i zabawy różnych stanów, w kraju calym lub niektórych tylko prowincjach, Warszawa 1881; Z. Gloger, Skarbczyk I. Zabawy, gry, zagadki, żarty, przypowieści, Warszawa 1886; Lutnia dziecięca. Marsze, zabawy, piosnki, wiersz i układ Jadwigi Chrząszczewskiej, muzyka Felicji Ginejko, Warszawa 1894; E. Kacz, Gry i zabawy młodzieży oraz znaczenie ich w wychowaniu, Lwów 1895; A. Stefański, Zabawy zimą. Opracował Stary Maciej, Mikołów 1899; idem, Gry i zabawy na wolnym powietrzu. Opracował Stary Maciej, Mikołów 1898; idem, Wesole chwile. Gry i zabawy towarzyskie w domu i poza domem, Mikołów 1898; idem, Gry i zabawy w kółku rodzinnym, Mikołów 1898; idem, Miłe zatrudnienia w wolnych chwilach. Zebrał i opracował Stary Maciej, Mikołów 1900; idem, Gry umysłowe. Zebrał i opracował Stary Maciej, Mikołów 1900; idem, Bawmy się. Gry i zabawy na wolnym powietrzu. Opracowat Stary Maciej, Mikołów 1900; M. Weryho, Gry i zabawy towarzyskie w pokoju i na dworze, Warszawa 1900; eadem, Jak zajać dzieci w wieku przedszkolnym. Pogadanki, rozmowy, zajęcia i zabawy, Warszawa 1901; eadem, Zabawy i zajęcia dziecięce, Warszawa 1909; eadem, Roboty z papieru, Warszawa 1922; Łatwiejsze gry i zabawy dla młodszych dzieci. Trudniejsze gry $i$ zabawy dla młodszych dzieci, w: W. Puffke, Zabawy, gimnastyka i pogadanki w szkółce freblowskiej, Poznań 1911, s. 137-359; E. Cenar, Gry i zabawy ruchowe różnych narodów, Lwów 1906; A. Hamburger, Gry ruchowe, Lwów 1909; H. Czechowiczówna, Gry i zabawy ruchowe, Lwów 1914, E. Cenar, Gry i zabawy ruchowe różnych narodów, Lwów 1901; red. J. Gebethnerówna, Z. Karasiówna, A. Filipowicz, Gry i zabawy ruchowe stosowane w ogrodach Raua, Warszawa 1916; M. Rościszewski, Gry i zabawy towarzyskie, Warszawa 1900; K. Kalinowski, Jak się zabawić - gry towarzyskie, Warszawa 1912. 

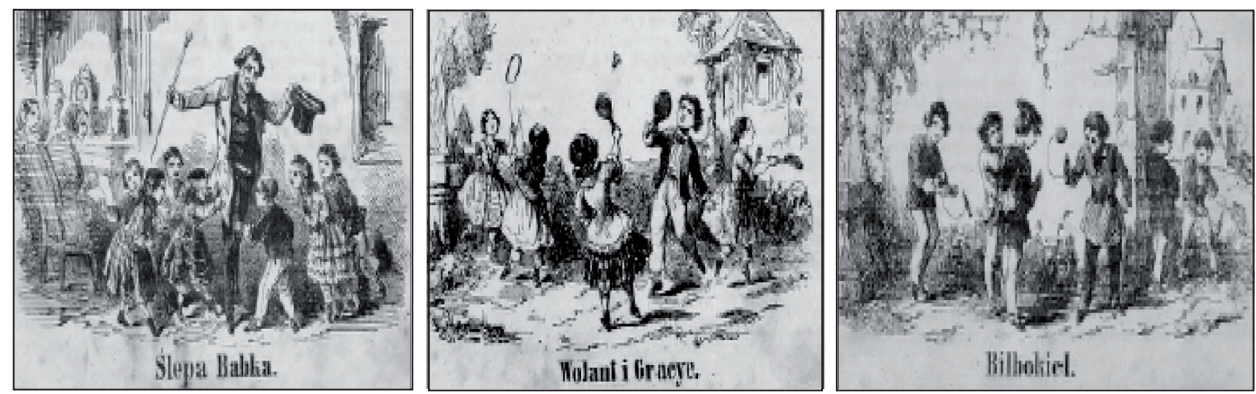

Gry i zabawki dla dzieci. Naśladowane z francuskiego. Z dziesięcia rycinami kolorowanemi, Warszawa 1851
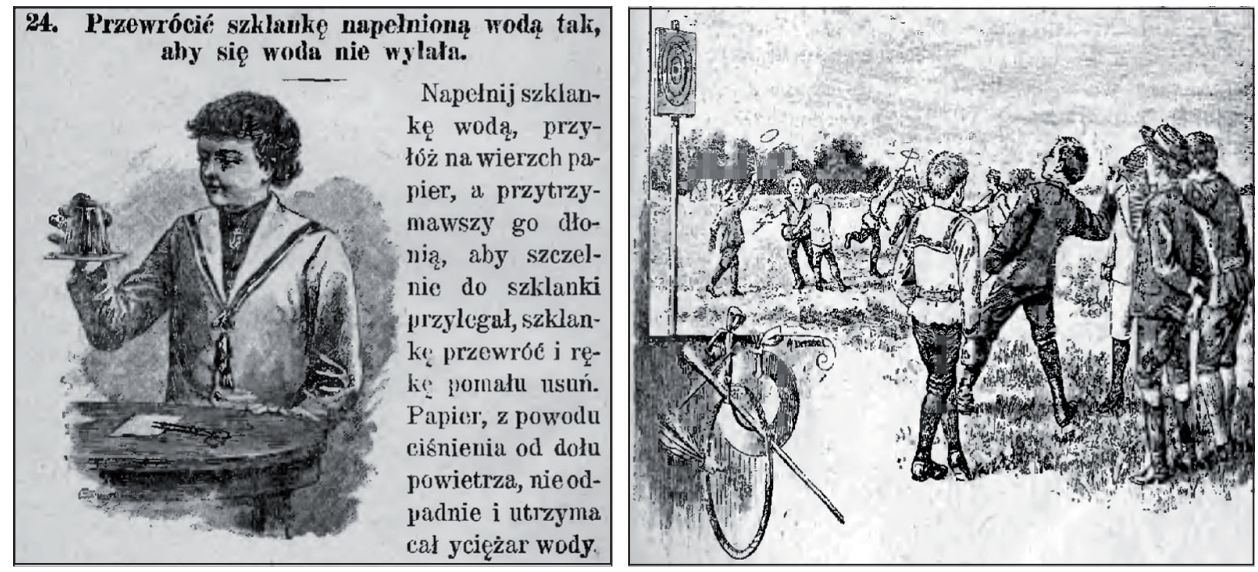

Stefański A., Miłe zatrudnienia w wolnych chwilach. Zebrał i opracował Stary Maciej, Mikołów 1900 (po lewej)

Rzucanie strzałką do tarczy, w: Bawmy się. Gry i zabawy na wolnym powietrzu. Opracował Stary Maciej, Mikołów 1900 (po prawej)

Warto nadmienić, że wskazówki do prowadzenia zabaw i gier zamieszczały także na swych łamach pisma pedagogiczne, poświęcone wychowaniu domowemu. Szczególne zasługi poniósł na tym polu warszawski „Przegląd Pedagogiczny”, na łamach którego od 1888 r. ukazywał się osobny dział adresowany specjalnie dla matek i opiekunek najmłodszych dzieci, od 1891 r. nazwany Ogródkiem dziecięcym. W dziale tym, obok rozpraw o charakterze teoretyczno-szkoleniowym, poświęconym wychowaniu, higienie i zdrowiu dziecka, znajdowały się także wskazówki metodyczne dotyczące zabaw i zajęć dziecięcych. Również np. na łamach „Dziecka”, w początku wieku XX ukazywały się działy pt. Gry i zabawy dla dzieci i młodzieży, z podziałem na zabawy dla dzieci młodszych i starszych; a także dział Zajęcia młodszych dzieci prezentujący pomysły na zabawy i zajęcia ręczne, wraz z wzorami wykonywanych przedmiotów i zabawek. Także wiele z pism 
adresowanych do wszystkich warstw społecznych, a wydawanych w różnych częściach terenów ziem polskich zawierało dodatki dla dzieci, w których zamieszczano łamigłówki obrazkowe, szarady, rebusy i zagadki, uprzyjemniające czas najmłodszym czytelnikom.

Podsumowując zaprezentowane powyżej wybrane aspekty problematyki zabaw i zabawek dziecięcych w drugiej połowie XIX i na początku XX w. należy stwierdzić, że tematyka zachowań ludycznych w minionych wiekach jest niezwykle interesującym i bogatym eksploracyjnie przedmiotem badań, wartym wnikliwych i pogłębionych analiz. Świadczy o tym z pewnością dające się zauważyć w ostatnich latach rosnące zainteresowanie tą tematyką przedstawicieli nauk społecznych i humanistycznych - socjologów, filozofów, historyków, historyków sztuki, literaturoznawców, pedagogów, psychologów, antropologów. Warto z pewnością, by badacze do prowadzonych analiz wykorzystywali obok źródeł pisanych także materiały ikonograficzne, niezwykle bogate i różnorodne.

Podkreślić należy, że omówione tu wybrane problemy zabaw i zabawek dziecięcych drugiej połowy XIX i początku XX z wykorzystaniem grafik z epoki wieku są jedynie przyczynkiem do dalszych analiz źródłowych w tym zakresie. Warto podjąć się analizy innych źródeł ikonograficznych, np. malarstwa czy fotografii, na których dzieci często prezentowane są w otoczeniu zabawek czy podczas czynności zabawowych. Warto zadać sobie także pytanie, czego nie widać na grafikach czy fotografiach, jakich zabaw i zabawek nie pokazywano w przyjętym kanonie tworzenia materiałów ikonograficznych danej epoki. Pól badawczych pozostających do odkrycia jest więc jeszcze bardzo wiele.

Autorka tekstu żywi nadzieję, że stanie się on przydatny podczas zajęć z historii czy to w klasie szkolnej czy podczas zajęć z historii wychowania.

Tekst powstał $\mathrm{w}$ ramach prac nad realizacją grantu nt. „Zabawki dziecięce na ziemiach polskich do końca XIX wieku” (grant NCN OPUS 4, nr 2012/07/B/HS3/00899). 